BMC

Cancer

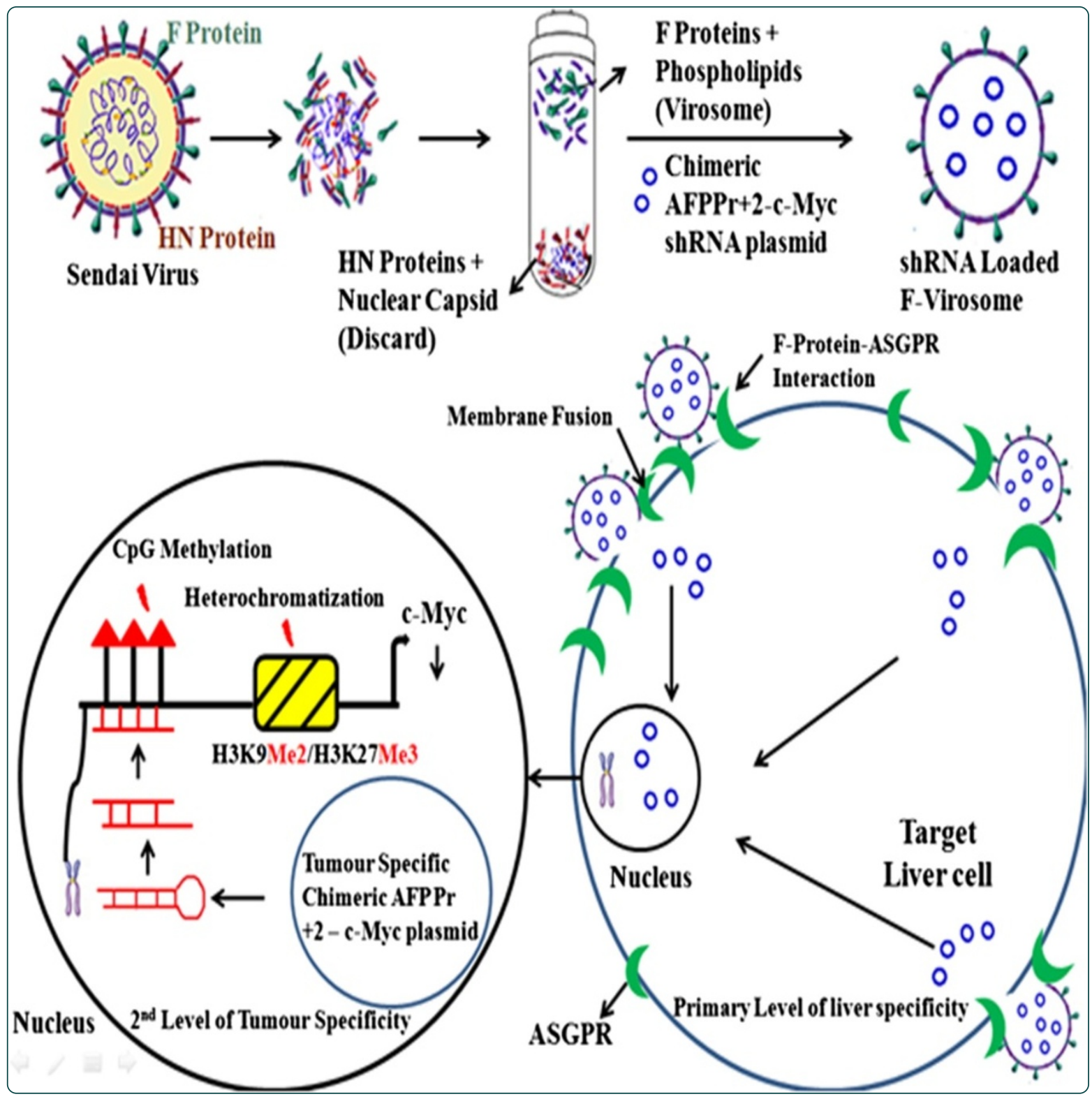

Combination of hepatocyte specific delivery and transformation dependent expression of shRNA inducing transcriptional gene silencing of $c-M y c$ promoter in hepatocellular carcinoma cells

Zakaria et al. 


\title{
Combination of hepatocyte specific delivery and transformation dependent expression of shRNA inducing transcriptional gene silencing of $c-M y c$ promoter in hepatocellular carcinoma cells
}

Mohammad Khalid Zakaria ${ }^{1 \dagger}$, Imran Khan ${ }^{1 \dagger}$, Prashant Mani ${ }^{2}$, Parthaprasad Chattopadhyay ${ }^{1 *}$, Debi P Sarkar ${ }^{2 *}$ and Subrata Sinha $a^{1,3^{*}}$

\begin{abstract}
Background: A specific targeting modality for hepatocellular carcinoma (HCC) could ideally encompass a liver cell specific delivery system of a transcriptional unit that is active only in neoplastic cells. Sendai virosomes, derived from Sendai viral envelopes, home to hepatocytes based on the liver specific expression of asialoglycoprotein receptors (ASGPRs) which are recognized by the Sendai virosomal fusion (F) proteins. As reported earlier by us and other groups, transcriptional gene silencing (TGS) does not require continuous presence of the effector siRNA/ shRNA molecule and is heritable, involving epigenetic modifications, leading to long term transcriptional repression. This could be advantageous over conventional gene therapy approaches, since continuous c-Myc inactivation is required to suppress hepatocarcinoma cells.

Methods: Exploiting such virosomal delivery, the alpha-fetoprotein (AFP) promoter, in combination with various tumour specific enhancers, was used to drive the expression of shRNA directed against ME1a1 binding site of the proto-oncogene c-Myc P2 promoter, in order to induce TGS in neoplastic liver cells.

Results: The dual specificity achieved by the Sendai virosomal delivery system and the promoter/enhancer guided expression ensured that the shRNA inducing TGS was active only in liver cells that had undergone malignant transformation. Our results indicate that such a bimodal therapeutic system induced specific activation of apoptosis in hepatocarcinoma cells due to heterochromatization and increased DNA methylation of the CpG islands around the target loci.

Conclusions: The Sendai virosomal delivery system, combined with AFP promoter/enhancer expression machinery, could serve as a generalized mechanism for the expression of genes deleterious to transformed hepatocarcinoma cells. In this system, the epigenetic suppression of c-Myc could have an added advantage for inducing cell death in the targeted cells.
\end{abstract}

Keywords: Hepatocellular carcinoma, Sendai virosome, Asialoglycoprotein receptors, Transcriptional gene silencing, shRNA, c-Myc, Alpha-fetoprotein, Heterochromatization, DNA methylation

\footnotetext{
*Correspondence: parthoaiims@hotmail.com; dpsarkar59@gmail.com; sub_sinha@hotmail.com

${ }^{\dagger}$ Equal contributors

'Department of Biochemistry, All India Institute of Medical Sciences, New

Delhi 110029, India

${ }^{2}$ Department of Biochemistry, University of Delhi, South Campus, Benito

Juarez Road, New Delhi 110021, India

Full list of author information is available at the end of the article
}

\section{Biomed Central}

(c) 2014 Zakaria et al.; licensee BioMed Central Ltd. This is an Open Access article distributed under the terms of the Creative Commons Attribution License (http://creativecommons.org/licenses/by/4.0), which permits unrestricted use, distribution, and reproduction in any medium, provided the original work is properly credited. The Creative Commons Public Domain Dedication waiver (http://creativecommons.org/publicdomain/zero/1.0/) applies to the data made available in this article, unless otherwise stated. 


\section{Background}

Hepatocellular carcinoma (HCC) is the sixth most prevalent cancer and the third leading cause of worldwide cancer related deaths [1]. Genes of fetal or embryonic origin are often re-expressed in various tumours and alpha-fetoprotein (AFP) expression has been shown to be re-activated in HCC [2]. In cancer gene therapy, the biggest challenges are cell specific targeting and tumour selective expression of the therapeutic gene. A number of reports have raised the issue of specificity and efficiency of gene transfer [3,4], specifically to neoplastic cells. Specificity can be at two levels. Firstly, it could be at the level of delivery to a particular cell type. Usually, cell type specific antibodies/ligand-receptor units can be used [5-7]. These include binding to generalized ligands like the transferrin or folate receptors [8-11] or antibodies to cell surface antigens [12,13]. Sendai virosomes specifically fuse with the hepatocytes through their fusion (F) protein's terminal galactose moiety, that binds specifically with asialoglycoprotein receptors (ASGPRs) present only on the surface of hepatocytes [14]. The Sendai F-virosomal system, lacking the hemagglutinin neuraminidase $(\mathrm{HN})$ protein, is non-toxic and comparatively non-immunogenic. One of us earlier (D.P.S), has successfully demonstrated the expression of human uridinediphosphoglucuronate glucuronosyltransferase-1A1 (hUGT1A1) gene in the hepatocytes of Gunn rats for the treatment of jaundice [15]. The expression of a transgene might be low due to its lysosomal translocation and failure to integrate into the host genome. Sendai F-virosome mediated delivery overcomes this limitation since the entrapped cargo is directly delivered into the cytoplasm, thus evading the endosomal pathway $[16,17]$. This could enhance transgene expression and its longevity for therapeutic purposes.

Another level of specificity is at the level of tumour specific promoters [18]. This relies on the fact that several genes, including oncofetal genes are expressed upon cell transformation, implying that the activation of such promoters takes place only in the transformed but not in the normal cells. Such neoplasia activated promoters include carcinogenic embryonic antigen (CEA), prostate specific antigen (PSA), L-plastin, osteocalcin, midkine etc. [19]. For liver neoplasms, it has been shown that an AFP promoter could help achieve a HCC-targeted gene therapy [20-22]. Often, the tumour specific promoters are weak which can be augmented by utilizing various tumour specific enhancers [23] without compromising the specificity. The $5^{\prime}$ flanking region of the AFP gene consists of several enhancer like sequences [24] where one of the core enhancer region can augment gene expression in an engineered construct [25]. However, the possibility of other enhancers could also be explored.
$c-M y c$ regulates several cellular processes [26] and is crucial for stem cell maintenance [27]. It is also essential for normal growth and proliferation since its inactivation produces lethal effects $[28,29]$, indicating its level has to be tightly regulated. Down-regulation of $c-M y c$ both in vitro and in vivo has been shown to induce growth inhibition and differentiation of HCC [30-32]. ME1a1 binding site between $\mathrm{P} 1$ and $\mathrm{P} 2$ promoter of $c-M y c$ is required for sustenance of transcriptionally active dual $c-M y c$ promoters [33]. Since the P2 promoter is associated with $75-90 \%$ of the $c-M y c$ transcripts [26], it serves as an ideal candidate for targeting therapy. We have previously demonstrated that siRNA against $c-M y c$ could induce TGS in glioma cells, leading to increased cell death [34].

Post-transcriptional gene silencing (PTGS) involves direct cleavage of the target mRNA by double stranded RNA (dsRNA) [35,36], whereas Transcriptional Gene Silencing (TGS) induces epigenetic modifications such as CpG methylation and heterochromatization (H3K9Me2 and $\mathrm{H} 3 \mathrm{~K} 27 \mathrm{Me} 3$ ) around the target loci [37-40]. The effects of TGS are heritable and lead to long term transcriptional repression of the target gene [41].

In the current study, we have tried to assess the combination of cell type specific delivery and tumour dependent activation for inducing TGS in hepatocellular carcinoma cells. There are no reports of TGS by shRNA driven through a tumour specific promoter delivered by a target specific vehicle. In order to impart strength and specificity to the induction of TGS, we have first generated novel combinations of the AFP promoter with AFP enhancer as well as with the nuclear factor kappa beta $\left(\mathrm{NF}_{\kappa} \mathrm{B}\right)$ response element to drive the expression of shRNA targeting $c-M y c$ P2 promoter. Usually shRNA has been expressed by constitutive polymerase (pol) III promoters [42] which fail to elicit tumour specificity. However, in this study, we have tried to achieve specificity as well as efficiency in transcription by using pol II based AFP promoter along with various enhancer elements. Since one of the key events in hepatic oncogenesis is the constitutive activation of NFKB transcription factor [43] and AFP [44], we have compared enhancer systems from both in our study.

Our results indicate that the Sendai virosomal delivery, combined with the AFP promoter/enhancer driven shRNA system, has the necessary specificity and efficiency to activate TGS in hepatocarcinoma cells, leading to cell death. The combination of both targeting entities is likely to be of an added advantage for cancer therapeutics.

\section{Methods}

\section{Cell culture}

HepG2, Huh7, and $\mathrm{CHO}$ cells were procured from American type culture collection (ATCC, USA) whereas Chang Liver cells were obtained from National centre 
for cell sciences (N.C.C.S), Pune. Cells were maintained in Dulbecco's Modified Eagle's Medium (DMEM; SigmaAldrich, Germany) supplemented with $10 \%$ calf fetal serum (Biowest, USA). The molecular characterization of Chang Liver cells was done before any experimentation (Additional file 1: Figure S1).

\section{Generation of AFP promoter/enhancer +25-luciferase reporter systems}

AFP promoter +25 - luciferase $(\mathrm{AFPPr}+25$ - luc): AFP promoter region encompassing -230 to +25 base pairs (bp) was PCR amplified using genomic DNA from HepG2 cells with primers having restriction sites MluI and NheI at 5' and 3' ends respectively. The PCR amplified product was cloned into pGL3-Basic firefly luciferase reporter vector (Promega, USA) and confirmed both by restriction digestion and DNA sequencing. AFP enhancer AFP promoter +25 - luciferase (AFPEn-Pr + 25 - luc): Similarly, 700 bp AFP enhancer region was amplified using primers having $5^{\prime} \mathrm{KpnI}$ and 3' MluI restriction sites and cloned upstream to the AFP promoter in pGl3-Basic vector. NFkB enhancer - AFP promoter +25 - luciferase $(\mathrm{NF} \kappa \mathrm{BEn}-\mathrm{Pr}+25-\mathrm{luc})$ : Four copies of NFkB response elements of ten nucleotides (5'-GGGAATTTCC-3' $\mathrm{x}$ 4; [45]) were annealed and cloned upstream to the AFP promoter in pGl3-Basic vector with 5' KpnI and 3' MluI sites. Schematic representation of various chimeric AFP promoter driven luciferase reporter constructs are shown in Figure 1A and their clones in Additional file 2: Figure S2. Luciferase reporter under simian virus (SV) 40 promoter (SV40 - luc) served as a positive control.

\section{Generation of TGS inducing system: AFP promoter/ enhancer +2 c-Myc shRNA}

100 pmoles of both sense and antisense oligonucleotides of $c-M y c$ (with pre-added sticky ends; 5' BamHI and 3' HindIII) were suspended in $100 \mu \mathrm{l}$ of $1 \mathrm{X}$ Annealing Buffer (10 mM Tris-HCL pH 8.0, $1 \mathrm{mM}$ EDTA and $100 \mathrm{mM}$ $\mathrm{NaCl}$ ). Oligonucleotides were heated for few minutes in boiling water. Temperature was maintained at $95-100^{\circ} \mathrm{C}$ for 5 minutes and was allowed to cool over night to room temperature. Agarose Gel Electrophoresis was performed to analyze and excise annealed oligonucleotides.

Sequence of $c-M y c$ promoter region is shown in Additional file 2: Figure S3. shRNA targeting $c-M y c$ P2 promoter was designed using Invivogen's online siRNA wizard (http://www.sirnawizard.com/construct.php) and chemically synthesized by Integrated DNA Technologies, USA. Sequence of the test and scrambled (Scr; control) shRNA is enlisted in Table 1. AFP Promoter, AFP enhancer - AFP promoter and NFKB response element - AFP promoter regions were amplified up to +2 bp relative to the transcription start site (TSS) from the previously generated luciferase reporter constructs (AFPPr + 25 - luc;
AFPEn-Pr + 25 - luc; NFkBEn-Pr + 25 - luc respectively) with primers containing $5^{\prime}$ EcoRI and 3' BamHI restriction sites. Amplification up to $+2 \mathrm{bp}$ would minimize sense strand and ensure efficient processing of shRNA by RNAi machinery [46]. These fusion constructs were cloned along with test $c-M y c$ shRNA (5' BamHI and 3' HindIII sticky overhangs) in shRNA expression vector pSilencer 4.1 (Ambion, USA). The generated constructs are shown in Figure $2 \mathrm{~B}$ and were as follows: AFP promoter $+2-c-m y c$ shRNA (AFPPr $+2-$ myc), AFP enhancer - AFP promoter $-c-m y c$ shRNA (AFPEn$\mathrm{Pr}+2-\mathrm{myc}$ ) and NFKB responsive element - AFP promoter $-c$-myc shRNA (NFkBEn-Pr $+2-$ myc). Likewise scrambled $c-M y c$ shRNA was cloned downstream to the same promoter/enhancer constructs (AFPPr $+2-$ myc Scr; AFPEn-Pr +2 - myc Scr; NFkBEn-Pr +2 - myc $\mathrm{Scr}) . c-M y c$ test and scrambled shRNA were also cloned under cytomegalovirus (CMV) promoter (CMVPr - myc and CMVPr - myc Scr respectively) where CMVPr - myc served as a positive control. Annealing of oligonucleotides and schematic representation of all the clones are shown in Additional file 2: Figure S4-S6. All the clones were confirmed by restriction digestion and further authenticated by DNA sequencing from professional agencies.

\section{Transfection}

Cells were plated at $10^{5}$ cells per well in a six-well plate, $3 \times 10^{5}$ cells per $25 \mathrm{~cm}^{2}$ flask or $10^{6}$ cells per $75 \mathrm{~cm}^{2}$ flask (Corning, USA). Twenty-four hours later, they were transfected with different reporter or shRNA constructs using Lipofectamine ${ }^{\mathrm{TM}} 2000$ (Invitrogen, USA) as per the manufacturer's protocol.

\section{Dual luciferase assay}

All the three constructs: AFPPr + 25 - luc, AFPEn-Pr + 25 - luc and NFkBEn-Pr + 25 - luc (Figure 1A) were transfected in HepG2, Huh7, Chang Liver and $\mathrm{CHO}$ cells. After 48 hours, transactivation study was done by Dual Luciferase Assay (Promega, USA) following manufacturer's protocol. The firefly luciferase activity was normalized against Renilla luciferase activity and expressed relative to promoter-less pGl3-Basic control vector. Results are representative of three independent sets of experiments.

\section{Quantitative RT-PCR to evaluate c-Myc down-regulation and ShRNA expression}

On the $5^{\text {th }}$ and $6^{\text {th }}$ day, post transfection of various test/ scrambled shRNA constructs, RNA was isolated from HepG2, Huh7, Chang Liver and $\mathrm{CHO}$ cell lines using Trizol (Sigma-Aldrich, Germany). It was treated with DNase (MBI, Fermentas, USA) and quantified by Nanodrop 2000 (Thermo Fischer Scientific, USA). $1 \mu \mathrm{g}$ of RNA was converted to cDNA using random decamer 

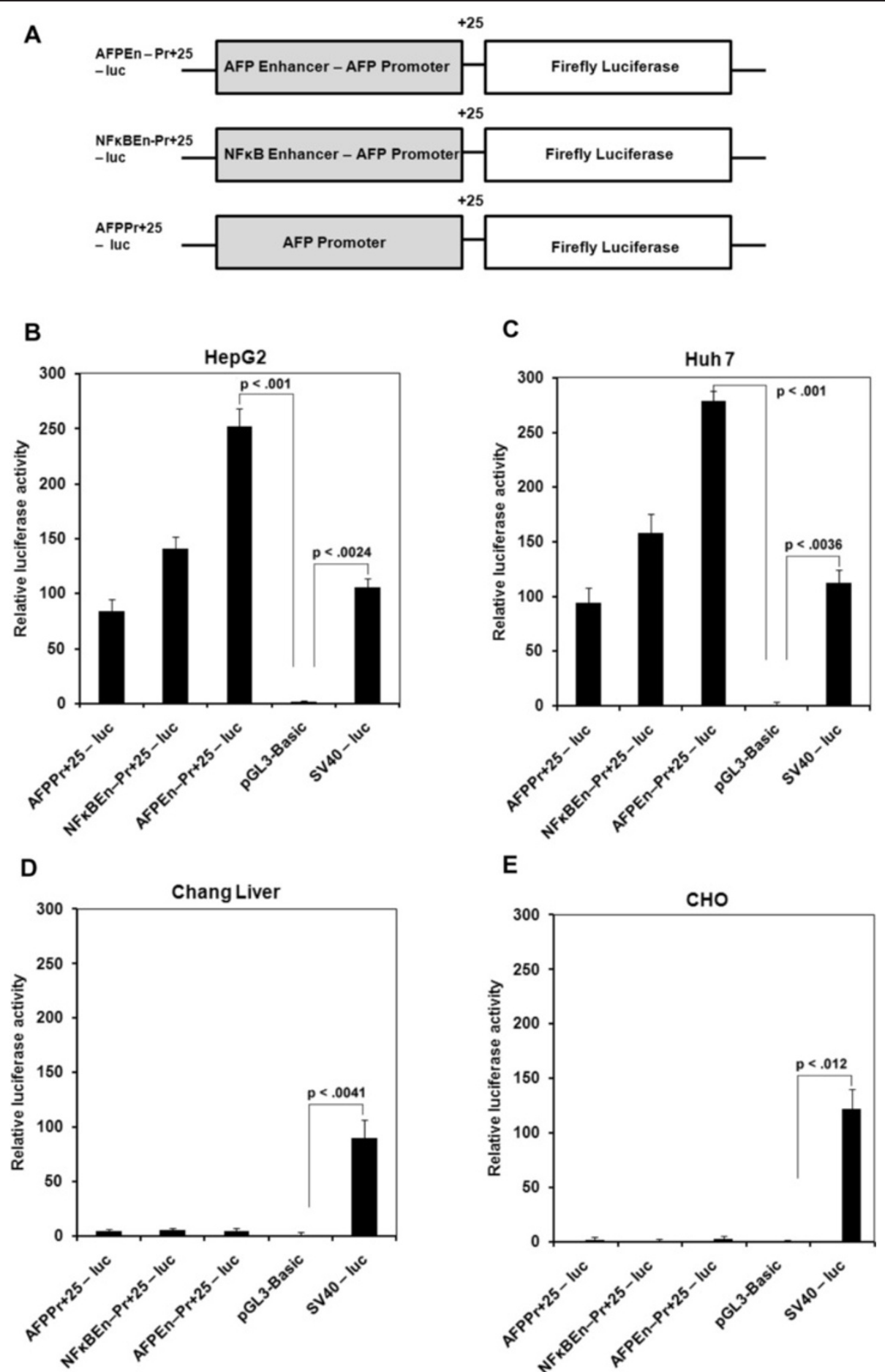

Figure 1 HCC specific expression of AFP promoter/enhancer system. (A) Various combinations of AFP promoter/enhancer fusion constructs with downstream luciferase reporter in pGI3-Basic vector. (B and C) 48 hours after transfection, the observed luciferase activity was maximum in the case of AFPEn-Pr + 25 - luc followed by NFKBEn-Pr + 25 - luc and lastly by AFPPr + 25 - luc in both HepG2 and Huh7 cells. (D and E) No luciferase activity was observed through AFP promoter/enhancer systems in untransformed Chang Liver and non-liver CHO cells.

primers and Moloney Murine Leukemia Virus Reverse Transcriptase (MBI, Fermentas, USA). Real time PCR (RT-PCR) was done on Rotor-Gene 6000 real time PCR machine (Corbett Research, Australia) with the reaction mix containing SYTO 9 green fluorescent dye (Invitrogen, USA). Accurate quantification was done by averaging the 
Table 1 Test and control c-Myc shRNA sequence

\begin{tabular}{|c|c|}
\hline Name & Sequence $5^{\prime}$ to $3^{\prime}$ \\
\hline $\begin{array}{l}\text { c-myc shRNA test } \\
\text { sense strand }\end{array}$ & $\begin{array}{l}\text { GATCCGAACGGAGGGAGGGATCGCGCTTTTTC } \\
\text { AAGAGAAGCGCGATCCCTCCCTCCGTTCTTA }\end{array}$ \\
\hline $\begin{array}{l}c-m y c \text { shRNA test } \\
\text { antisense strand }\end{array}$ & $\begin{array}{l}\text { AGCTTAAGAACGGAGGGAGGGATCGCGCTTC } \\
\text { TCTTGAAAAAGCGCGATCCCTCCCTCCGTTCG }\end{array}$ \\
\hline $\begin{array}{l}\text { c-myc shRNA } \\
\text { scrambled sense } \\
\text { strand }\end{array}$ & $\begin{array}{l}\text { GATCCAGCGGTCGAGACGTGGCGGAGATTTT } \\
\text { CAAGAGATCTCCGCCACGTCTCGACCGCTTTA }\end{array}$ \\
\hline $\begin{array}{l}\text { c-myc shRNA } \\
\text { scrambled antisense } \\
\text { strand }\end{array}$ & $\begin{array}{l}\text { AGCTTAAGCGGTCGAGACGTGGCGGAGATCTC } \\
\text { TTGAAAATCTCCGCCACGTCTCGACCGCTG }\end{array}$ \\
\hline
\end{tabular}

geometric mean of multiple internal control reference genes [47] such as $\beta$-Actin, 18S, GAPDH and relative expression was estimated by Relative Expression Software Tool (REST; [48]). Primers utilized are given in Additional file 3: Table S1.

Similarly, for $c-M y c$ shRNA quantitation, 1st-Strand cDNA Synthesis Kit (Agilent) was utilized, as per the manufacturer's protocol, and siRNA expression was estimated by RT-PCR. Custom made $c-M y c$ siRNA specific primer was obtained separately (sequence in the Additional file 3: Table S1). Luciferase shRNA under CMV promoter (CMV - luc shRNA) served as a control.

\section{Cell survival assay}

$2 \times 10^{4}$ cells seeded on to 24 well plates (Corning, USA) were transfected with various AFP promoter/enhancer driven shRNA constructs or their respective scrambled controls. On the $6^{\text {th }}$ day, cells were subjected to MTT (Sigma-Aldrich, Germany) assay for percent cell survival. Furthermore, cell survival was also evaluated by cell counting, post staining with trypan blue (Sigma-Aldrich, Germany), by following manufacturer's protocol.

\section{Apoptosis study}

$10^{5}$ cells were seeded in $25 \mathrm{~cm}^{2}$ cell culture flask (Corning, USA) followed by transfection with various shRNA constructs. On the $6^{\text {th }}$ day, cells were fixed overnight in $70 \%$ ice-cold ethanol. Staining of cells was done using Propidium Iodide (PI; Sigma-Aldrich, Germany) and fluorescence was captured using Flow Cytometer (BD Biosciences, USA). Percentage of apoptotic cells (subG1) and other cell cycle phases were estimated using WinMDI software (http://winmdi.software.informer. $\operatorname{com} / 2.8 /)$.

\section{Western blotting}

On the $6^{\text {th }}$ day, post transfection/virosomal delivery of various $c-M y c$ shRNA constructs, cell lysates were prepared using triple lysis buffer and protein was estimated by Pierce BCA Protein Assay Kit (Thermo-scientific, USA). Proteins were run on $5 \%$ to $12 \%$ SDS-PAGE gels and electro transferred to nitrocellulose membranes (Bio-Rad, USA). Blocking was done with $4 \%$ bovine serum albumin (Sigma-Aldrich, Germany) and Immunoblotting was done with requisite primary antibodies: antiactin (sc-8432), anti-c-Myc (9E10), anti-TERT (sc-377511) and anti-cyclin D3 (sc-6283); from SantaCruz Biotechnology, USA. Detection of specific proteins was done with horseradish peroxidase (HRP) conjugated secondary antibodies using ECL detection system (Applied Biosystems, USA).

\section{Sendai virus culture}

Sendai virus ( $Z$ strain) was grown in $10-11$ day old embryonated chicken eggs, and extracted by utilizing procedure described in our previous report [16].

\section{Generation of Sendai fusion (F) virosomes and R18 labeling}

Sendai F-virosomes were prepared as described earlier [14]. For Octadecyl Rhodamine B Chloride (R18; Invitrogen, USA) labeling, F-virosome (1 $\mathrm{mg} / \mathrm{ml})$ suspension was labeled by adding $10 \mu \mathrm{l}$ ethanolic soution $(1 \mathrm{mg} / \mathrm{ml})$ of R18 in falcon tube while vortex mixing. The mixture was incubated in dark at room temperature for 30 minutes. Excess unbound R18 was removed by ultracentrifugation at $1,00,000 \mathrm{~g}$ for 1 hour at $4^{\circ} \mathrm{C}$. The pellet was resuspended in $10 \mathrm{mM}$ phosphate buffered saline (PBS).

\section{Study of live cell fusion: kinetics of F-virosomes}

A measure of Sendai virus fusion with HepG2, Huh7, Chang Liver and $\mathrm{CHO}$ cells was done using R18 labeled F-virosomes. Heat inactivation of virosomal F-proteins was performed using procedure described in our earlier reports [16,17]. HepG2, Huh7, Chang Liver and $\mathrm{CHO}$ cells $\left(1 \times 10^{6}\right.$ cells $)$ were incubated with $2 \mathrm{mg}$ of R18 labeled F-virosomes for 1 hour at $4^{\circ} \mathrm{C}$. After incubation, cells were centrifuged at $2000 \mathrm{rpm}$ for 5 minutes to remove unbound virosomes. The pellet was suspended in $100 \mu \mathrm{l}$ of cold $10 \mathrm{mM}$ PBS. For measuring fusion kinetics, $50 \mu \mathrm{l}$ of the labeled F-virosome-cell complex was added in a cuvette having $3 \mathrm{ml}$ of PBS with $1.5 \mathrm{mM} \mathrm{Ca}^{2+}$ (pre-warmed to $37^{\circ} \mathrm{C}$ ). Fusion kinetics was studied by a spectrofluorimeter (FL3-22; Horiba, USA). For data normalization, percent fluorescence dequenching (\% FDQ) at a time point was calculated as per the equation: \% $\left.F D Q=\left[\left(F-F_{0}\right) / F_{t}-F_{0}\right)\right] \times 100$ where $F_{0}$ denotes fluorescence intensity at time point zero, $\mathrm{F}$ is the intensity at a given time point and $F_{t}$ is the intensity recorded when $0.1 \%$ Triton X-100 was added to the cell-virosome complex and is designated as fluorescence at "infinite" dilution of the probe $(100 \%)$. 


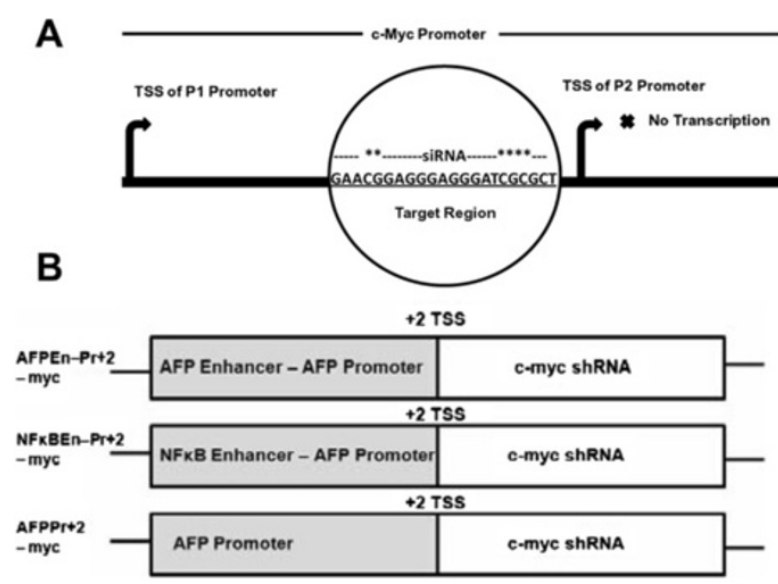

D

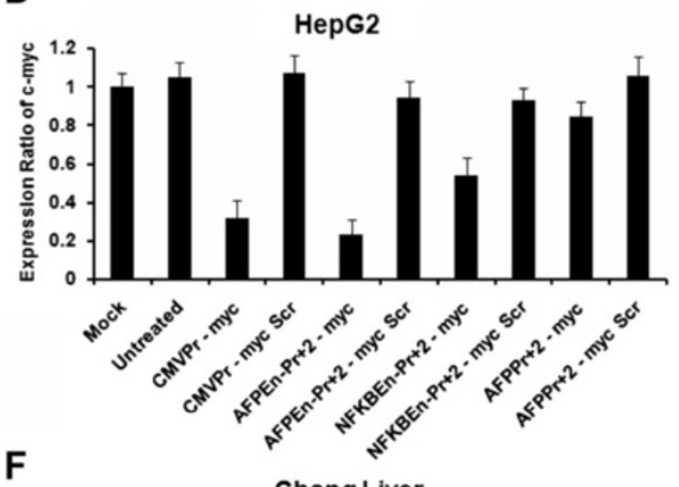

$\mathbf{F}$

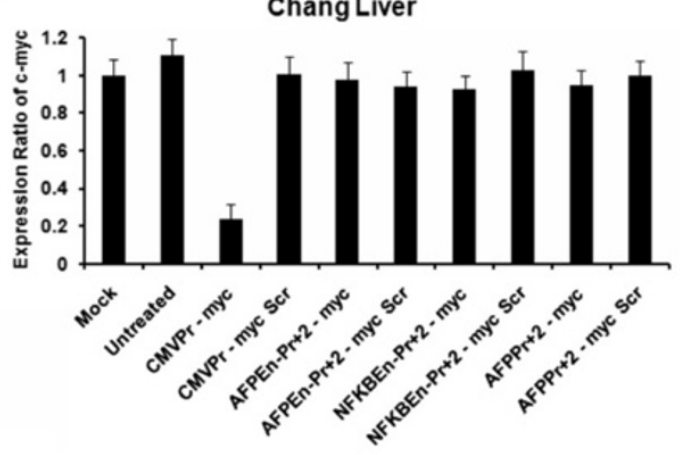

H
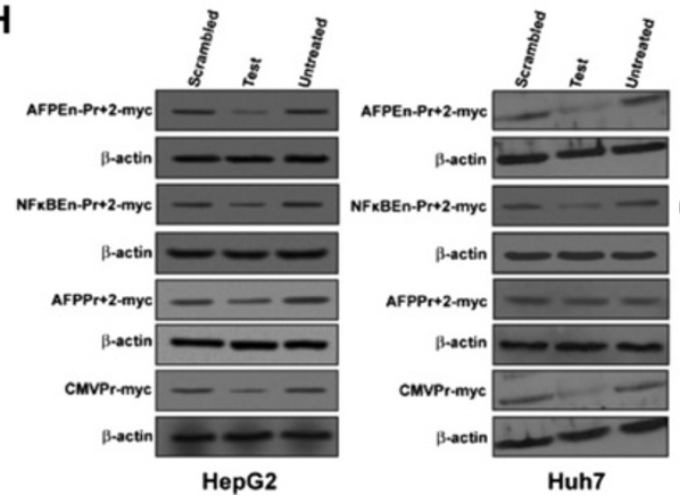

C

E

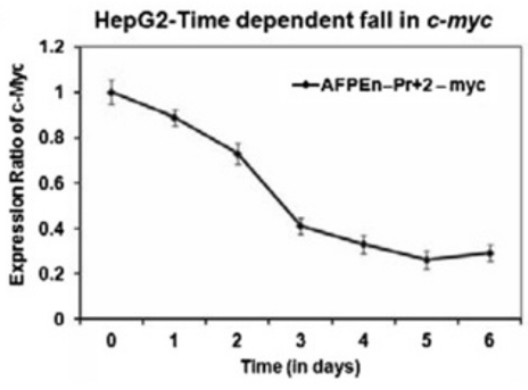

Huh7

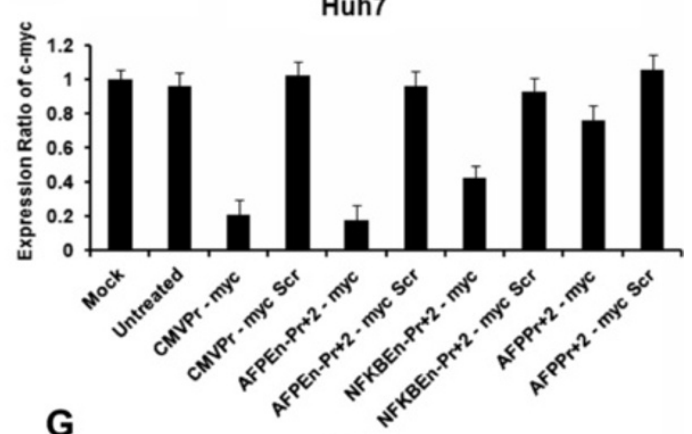

$\mathrm{CHO}$
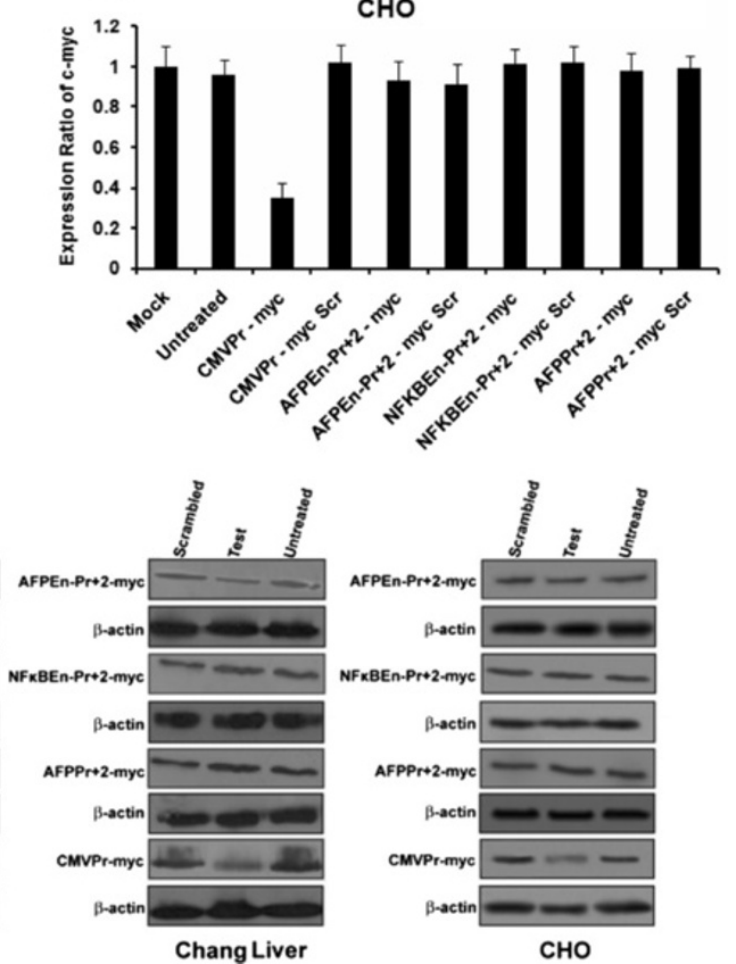

Figure 2 (See legend on next page.) 


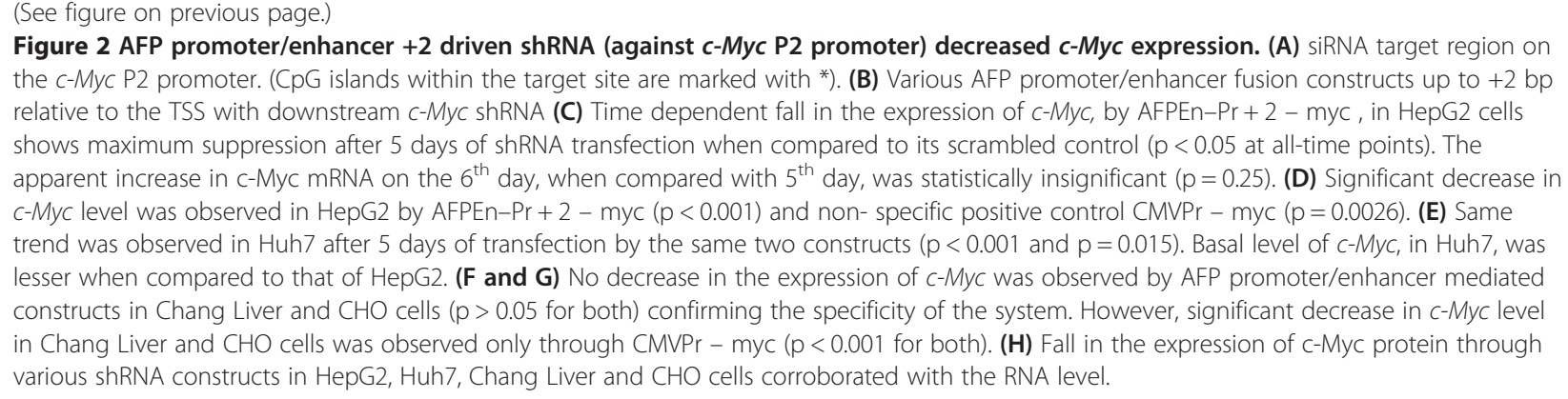

\section{Packaging and delivery of AFP promoter/enhancer +2 c-Myc shRNA constructs by Sendai F-virosomes}

$50 \mathrm{mg}$ of Sendai virus envelope was reduced with $3 \mathrm{mM}$ Dithiothreitol (DTT) at $37^{\circ} \mathrm{C}$. Viral genetic material and $\mathrm{HN}$ were removed from the virosomal suspension by treatment with non-ionic detergent Triton X-100 for 1 hour followed by ultra-centrifugation. From this detergent extract, supernatant was recovered and mixed with required amount of various AFP promoter/enhancer driven $c-M y c$ shRNA plasmids. This mixture was reconstituted by step-wise removal of detergent by utilizing SM-2 Biobeads (Bio-Rad, USA). Packaging of shRNA plasmids was confirmed by SDS based lysis and running the contents on $0.8 \%$ agarose gel. Cells were plated at $10^{5}$ cells per well in a six-well plate, $3 \times 10^{5}$ cells per $25 \mathrm{~cm}^{2}$ flask, or $10^{6}$ cells per $75 \mathrm{~cm}^{2}$ flask (Corning, USA) followed by transfection with $c-M y c$ shRNA loaded F-virosomes.

\section{CpG methylation study: bisulfite PCR and sequencing}

Following virosomal delivery of AFPEn-Pr $+2-$ myc or its scrambled control in HepG2 cells, genomic DNA was isolated on the $6^{\text {th }}$ day using Gen Elute Mammalian genomic DNA Miniprep Kit (Sigma-Aldrich, Germany). Bisulfite PCR was done using Epi Tech Bisulfite Kit (Qiagen, Germany) as per the manufacturer's protocol. http://bisearch.enzim.hu/ was utilized for designing specific primers. Primers were M13-tagged for sequencing of PCR products.

\section{Assessment of heterochromatization by chromatin immunoprecipitation (ChIP) assay}

Chromatin immunoprecipitation (ChIP) assay for H3K9Me2 and $\mathrm{H} 3 \mathrm{~K} 27 \mathrm{Me} 3$ was done using EZ ChIP kit (Millipore, USA) as per manufacturer's protocol. Input DNA, antiH3K9Me2 (mAbcam1220), anti-H3K27Me3 (mAbcam6002), anti-histone 3 acetylated (Upstate) and control mouse IgG antibody (Upstate) immunoprecipitated DNA was amplified using primers specific for the target region on the $c-M y c$ P2 promoter listed in Additional file 3: Table S1. Immunoprecipitation percentage was calculated as described by Haring et al. [49]. Centrosome of chromosome 16 served as a positive control, since it has $100 \%$ methylated histone tails.

\section{Suppression of histone deacetylase (HDAC) and DNA methyl transferase (DNMT)}

Trichostatin A (TSA; Sigma-Aldrich, Germany; 300nM) and 5-aza-2-deoxycytidine (AZA; Sigma-Aldrich, Germany; $5 \mathrm{mM}$ ) were prepared as per manufacturer's datasheet. Cells were pre-treated with TSA/AZA or both for 48 hours followed by virosomal delivery of the AFPEn-Pr $+2-$ myc or its scrambled control.

\section{Caspase 3/7 assay for evaluation of apoptosis after virosomal delivery of shRNA}

Caspase 3/7 activity of HepG2, Huh7 and Chang Liver cell lines was measured post virosomal delivery of AFPEn-Pr $+2-$ myc or AFPEn-Pr $+2-$ myc Scr by using caspase $3 / 7$ assay kit (Promega, USA) as per manufacturer's protocol.

\section{Statistical analysis}

All experiments including dual luciferase assay, cell survival assays and RT-PCR was repeated thrice and performed in triplicates. Western blotting, virosome fluorescence dequenching assay, Flow cytometric analysis, Bisulfite PCR, ChIP assay and capase 3/7 assay were repeated at least twice. Student's t-test was utilized to calculate the significance in all experiments and $\mathrm{p}<0.05$ was considered significant whereas $\mathrm{p}<0.001$ as highly significant. The data are shown as mean \pm SD.

\section{Results}

Characterization of the novel NFKB/AFP enhancer - AFP promoter +25 based constructs

The AFP enhancer - AFP promoter +25 (AFPEn-Pr + 25), NFkB response element - AFP promoter +25 (NFkBEn$\mathrm{Pr}+25)$ and AFP promoter $+25(\mathrm{AFPPr}+25)$ generated constructs (Figure 1A) were verified by sequencing. The sequence encompassing different restriction sites on pGl3Basic vector are given in Additional file 4: Figure S7. 


\section{AFP promoter/enhancer mediated expression is hepatocarcinoma specific}

The generated luciferase constructs were transfected in both transformed and untransformed cell lines and their proficiency was determined by dual luciferase assay after 48 hours. In the transformed HCC cells, HepG2 and Huh7, the luciferase activity was highest with AFPEn$\mathrm{Pr}+25$ - luc followed by NFkBEn-Pr $+25-$ luc and lastly by AFPPr +25 - luc, indicating the relative activity of the AFPEn-Pr +25 in the transformed cells is significantly higher than SV40 promoter (Figure 1B and C). However, in the untransformed Chang Liver and nonhepatic $\mathrm{CHO}$ cells, significant activity was observed only with SV40 - luc and not in case of AFP promoter/ enhancer constructs (Figure 1D and E).

\section{Decrease in c-Myc level by TGS inducing shRNA}

Various $c-M y c$ shRNA constructs, against $c-M y c$ P2 promoter (Figure 2A), were generated as described in methods (Figure 2B). AFPEn-Pr $+2-$ myc and AFPEn$\mathrm{Pr}+2-$ myc Scr were transfected in HepG2 cells and fall in the expression of $c-M y c$ was evaluated consecutively for 6 days by RT-PCR (Figure 2C). The decrease in c-Myc mRNA level was significant at all-time points $(\mathrm{p}<0.05)$ with respect to its control and was maximum on the $5^{\text {th }}$ day. Slight apparent increase on the $6^{\text {th }}$ day when compared to that of $5^{\text {th }}$ day was insignificant $(p=0.25)$. Similarly, fall in the $c-M y c$ expression, by other shRNA constructs was also evaluated 5 days post transfection in HepG2 cells (Figure 2D). Similar results were observed for Huh7 cells (Figure 2E). However, the absolute levels of $c-M y c$ were higher in HepG2 as compared to Huh7. No significant decrease in $c-M y c$ was observed in the Chang Liver and CHO cells ( $\mathrm{p}>0.05$ for both; Figure 2F and G). The levels of c-Myc protein (Figure $2 \mathrm{H}$ ) corroborated with mRNA data but the tissue non-specific CMV promoter driven $c-M y c$ shRNA (CMVPr - myc) decreased the level of $c-M y c$ even in Chang Liver and CHO cells $(\mathrm{p}<0.001$ for both; Figure 2F and G).

\section{TGS of c-Myc reduced cell survival and increased apoptosis}

To examine whether decrease in the expression of $c-M y c$, by TGS, affects cell growth, both cell survival and apoptosis were evaluated. MTT assay, on the $6^{\text {th }}$ day post shRNA transfection, revealed decrease in cell survival of the transformed cell line HepG2 and Huh7 ( $p<0.05$ for both; Figure 3A and Additional file 4: Figure S8), however, Huh7 cells were less responsive to $c-M y c$ knockdown. No such inhibitory effects were observed in the case of untransformed Chang Liver cell line. On the other hand, CMVPr - myc showed significant cell killing and suppression even in Chang Liver cells due to its non-specific nature $(p=0.019$; Figure 3B). Cell survival, of HepG2, Huh7 and Chang Liver cells, was further estimated by trypan blue staining followed by cell counting, which corroborated with the MTT data (Figure 4 and Additional file 4: Figure S9; $\mathrm{p}<0.05$ ). Any molecular analysis beyond 6 days was not possible due to complete detachment of HepG2 cells treated with the AFPEn-Pr + $2-$ myc when compared to the scrambled control.

Flow cytometric studies by PI staining showed that the percentage of apoptotic cells (sub G1 proportion) in HepG2 was in concordance with the strength of the AFP promoter/enhancer constructs driving the shRNA expression (Figure 5A). Similar trend was observed in the case of Huh7 cells but to a lesser degree (Additional file 4: Figure S10). Significant apoptosis in Chang Liver was seen only by CMVPr - myc and not by any of the AFP promoter/enhancer mediated $c-M y c$ shRNA constructs (Figure 5B). $c-M y c$ suppressed cells (HepG2 and Huh7), in addition to apoptosis (subG1 proportion), were found to be within the G0-G1 phase with decreased $S$ and G2M phase. Suppression of $c-M y c$, by TGS, had a profound effect on the cell survival and apoptosis of HepG2 cells when compared with that of Huh7.

\section{Specific binding of Sendai F-virosomes to cells of liver origin}

Once the specificity of $c-M y c$ suppression in HCC cell lines was established, we aimed to increase the level of specificity further by packaging the AFP promoter/ enhancer shRNA constructs within the Sendai virosomes for liver specific delivery. Real time fusion kinetics by fluorescence dequenching assay revealed that Sendai Fvirosomes bind specifically to hepatic cells (HepG2, Huh7 and Chang Liver) and not with control non hepatic cell line $\mathrm{CHO}$. Virosomes with inactivated F-proteins (HC: Heat control), displayed poor fusion even with HepG2 cells, confirming the specific fusion via F-protein and ASGPR of the hepatocytes (Figure 6A). The difference in the fusion observed might be dependent upon the number of ASGPRs expressed by various cell types.

Once significant fusion was confirmed, the generated constructs were packaged and delivered by Sendai Fvirosomes to both transformed and untransformed liver cells. Time dependent fall in the $c-M y c$ level post virosomal delivery in HepG2 cells (Figure 6B) was highly comparable to that by conventional method (Figure $2 \mathrm{~B}$ ). Maximum suppression of $c-M y c$ was observed on the $5^{\text {th }}$ day with AFPEn-Pr $+2-$ myc and slight increase on the $6^{\text {th }}$ day when compared to the $5^{\text {th }}$ was insignificant $(p=0.41)$. Significant fall in the expression of $c-M y c$ mRNA was seen both in HepG2 and Huh7 by other AFP promoter/enhancer constructs, $(\mathrm{p}<0.05$ for both; Figure $6 \mathrm{C}$ and D). Even though the fluorescence dequenching experiments demonstrated fusion of F-virosomes with Chang Liver, TGS was not effective in these cells due to 

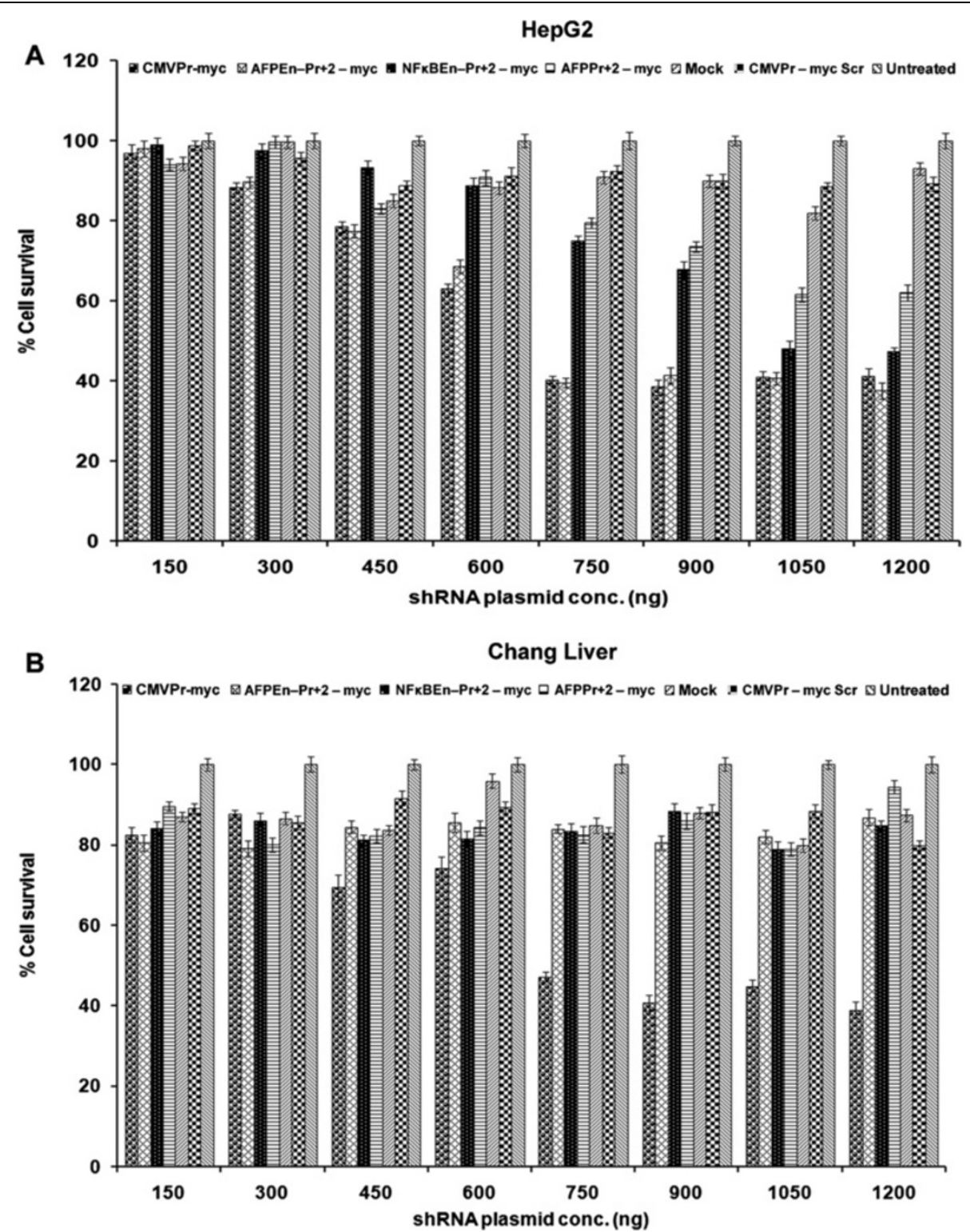

Figure 3 c-Myc suppression by TGS reduced cell survival. (A) HepG2 cells were transfected with various AFP promoter/enhancer driven test/ control shRNAs in different doses and percent cell survival was evaluated by MTT assay on the $6^{\text {th }}$ day. HepG2 cells showed decrease in cell survival with the increasing dose of the constructs and this decrease in cell survival was dependent upon the strength of each construct when compared to its control $(p<0.05)$. (B) In untransformed Chang Liver cell line, decrease in cell survival was observed only by CMVPr $-\mathrm{myc}(\mathrm{p}=0.019)$.

inactivation of AFP promoter/enhancer system (Figure 6E). Decrease in c-Myc protein levels were in concordance with its mRNA levels (Figure 6F).

No interferon response is mounted by c-Myc shRNA

Entry of dsRNA into the cell might lead to non-specific interferon (IFN) responses [50] which involves the activation of the PKR/RNase L pathway ultimately inducing an IFN marker 2,5-oligoadenylate synthetase 1 (OAS1) [51]. There was no significant induction of OAS1 in HepG2, Huh7 and Chang Liver cells ( $p>0.05$ at all points) post 5 days of shRNA delivery through F-virosomes; indicating the absence of an IFN response (Figure 7A). Furthermore, no significant increase in the levels of OAS1 was observed in 24, 48, 72 and 96 hours ( $\mathrm{p}>0.05$ at all points) after similar treatment of HepG2 cells (Additional file 4: Figure S11), ruling out IFN response being generated even at earlier time points following F-virosomal delivery of the entrapped shRNA constructs.

\section{c-Myc inactivation caused down-regulation of other} proliferative genes

$c-M y c$ regulates growth and proliferation by regulating various genes [26]. Cyclin D3 as well as human telomerase 


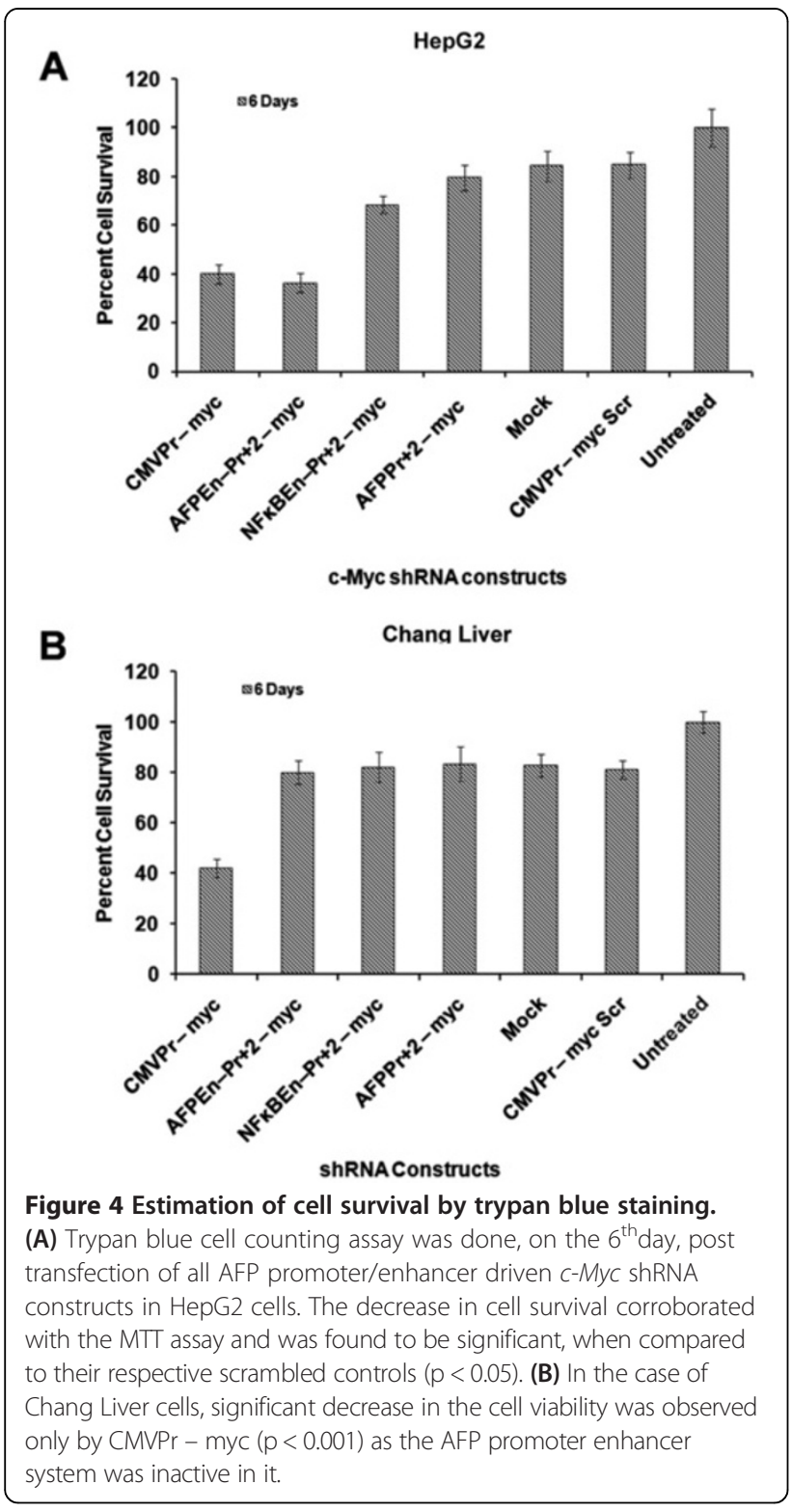

reverse transcriptase (hTERT) were studied in HepG2 cells at both mRNA and protein level. Fall in $c-M y c$ by F-virosomes loaded with AFPEn-Pr $+2-$ myc led to significant decrease in Cyclin D3 and hTERT both at mRNA $(\mathrm{p}=0.0022$ and $\mathrm{p}<0.001)$ and protein levels, suggesting the down-regulation of $c-M y c$ effector molecules (Figure 7B and C).

\section{Increase in caspase $3 / 7$ activity following TGS of $c-M y c$}

To validate the activation of apoptosis after $c-M y c$ suppression by chimeric AFP promoter driven $c-M y c$ shRNA, caspase 3/7 activity was evaluated in HepG2, Huh7 and Chang Liver cell lines, 5 days after virosomal delivery of AFPEn-Pr $+2-$ myc (Figure 7D). The increase in caspase activity was in agreement with the magnitude of chimeric AFP promoter driving the shRNA. In HepG2 cells, significant increase in caspase $3 / 7$ activity was observed $(\mathrm{p}=0.005)$ as compared to its scrambled control, however, activation of caspase 3/7 was to a lesser degree in Huh7 ( $\mathrm{p}=0.035)$. No increase in the activity was seen in Chang Liver cells $(\mathrm{p}=0.38)$.

\section{shRNA induced TGS by chromatin condensation and CpG methylation of $c-M y c$ P2 promoter}

To evaluate the mechanism by which shRNA acted on the target region, the chromatin status of the $c-M y c$ P2 promoter was evaluated by ChIP assay, on the $6^{\text {th }}$ day, post virosomal delivery of the AFPEn-Pr $+2-$ myc construct in HepG2 cells. ChIP followed by quantitative RT-PCR revealed that $c-M y c$ shRNA mediated TGS was associated with H3K9 dimethylation and H3K27 trimethylation. Cells pre-treated with HDAC inhibitor TSA showed reduced enrichment of histone chromatin marks even in the presence of AFPEn-Pr $+2-$ myc. This indicated the likely involvement of HDACs in gene silencing of $c-M y c$ (Figure 8A). Similarly, we checked the acetylation status of the target region following AFPEn-Pr $+2-$ myc transfection, by utilizing anti-histone 3 acetylated antibodies. Significant decrease in the acetylation level was observed post $c-M y c$ suppression on day 6 (Figure 8B; $\mathrm{p}=0.016$ ). However, in the presence of TSA, no decrease was observed $(p>0.05)$ as the shRNA failed to recruit HDACs.

Furthermore, the methylation status of $\mathrm{CpG}$ islands was checked by bisulfite PCR followed by DNA sequencing. Methylation of CpG 8, 9 and 10, when compared to scrambled control, was observed in the test shRNA treated cells (Figure 8C and D). Moreover, such effect was abrogated by pre-treatment of HepG2 cells with DNMT inhibitor AZA, confirming the possible recruitment of DNMTs, by shRNA, to the target site (Figure 8E).

We also determined the effect of TSA/AZA or both in combination on $c-M y c$ transcription in HepG2 cells by RT-PCR. Cells pre-treated with both AZA and TSA showed no significant decrease in $c-M y c$ levels by AFPEn$\operatorname{Pr}+2-$ myc on the $6^{\text {th }}$ day after treatment. Additionally, when the cells were pretreated with AZA or TSA individually, AFPEn-Pr $+2-$ myc down-regulated $c$ $M y c$ levels significantly, indicating that both HDACs and DNMTs are involved in gene silencing of $c-M y c$ (Additional file 5: Figure S12).

It is known that TGS can continue for a significant number of days after transfection [39,52,53]. In this study, we performed real time PCR to study the dynamics of $c$ Myc mRNA as well as shRNA expression after transient transfection of various shRNA constructs in HepG2 cells. For AFPEn-Pr $+2-$ myc construct, shRNA was maximally expressed after 48 hours while declining to around $18 \%$ of the maximum on day 6 (Additional file 5 : 


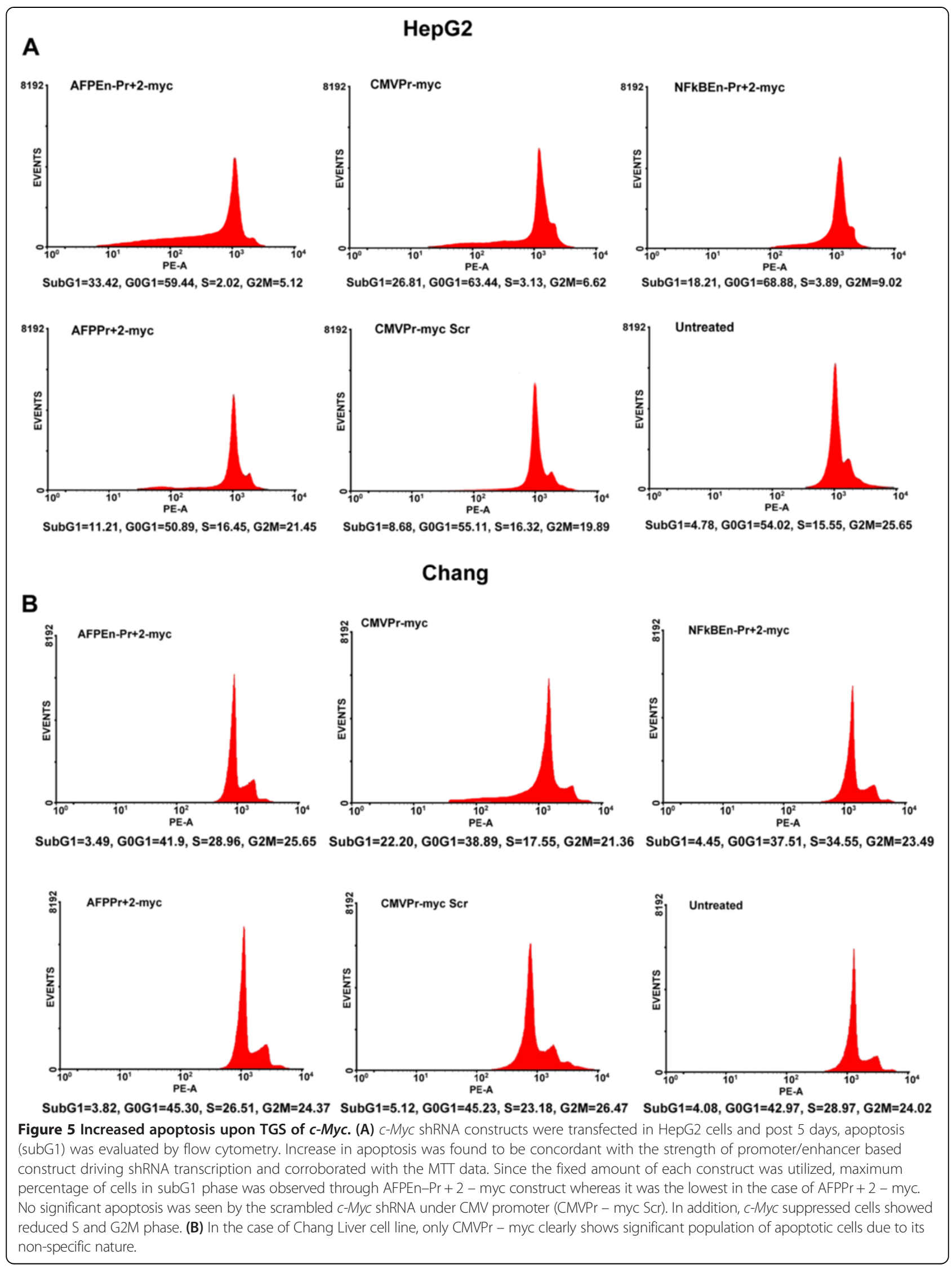



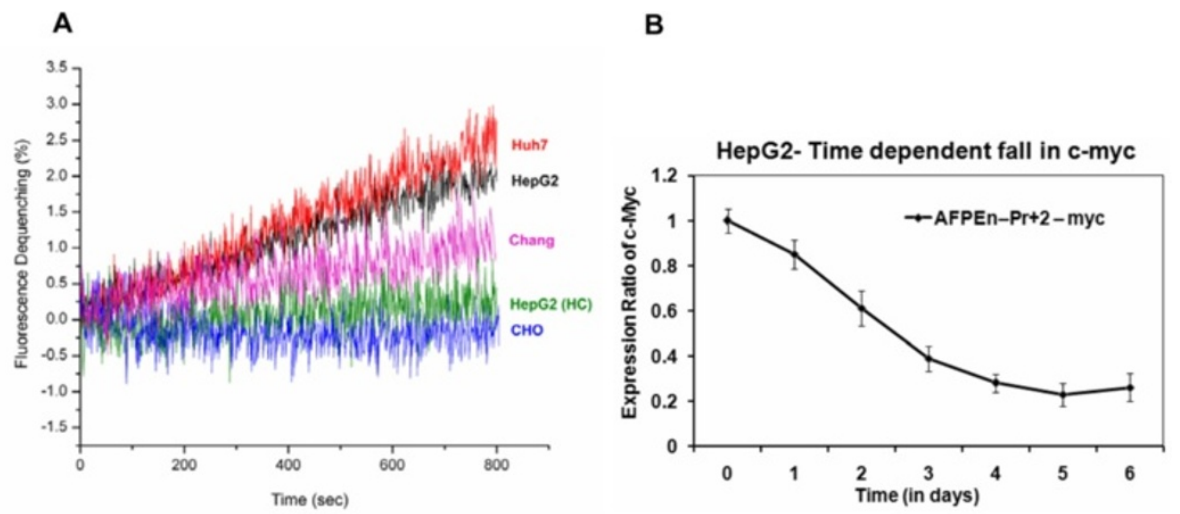

C

D
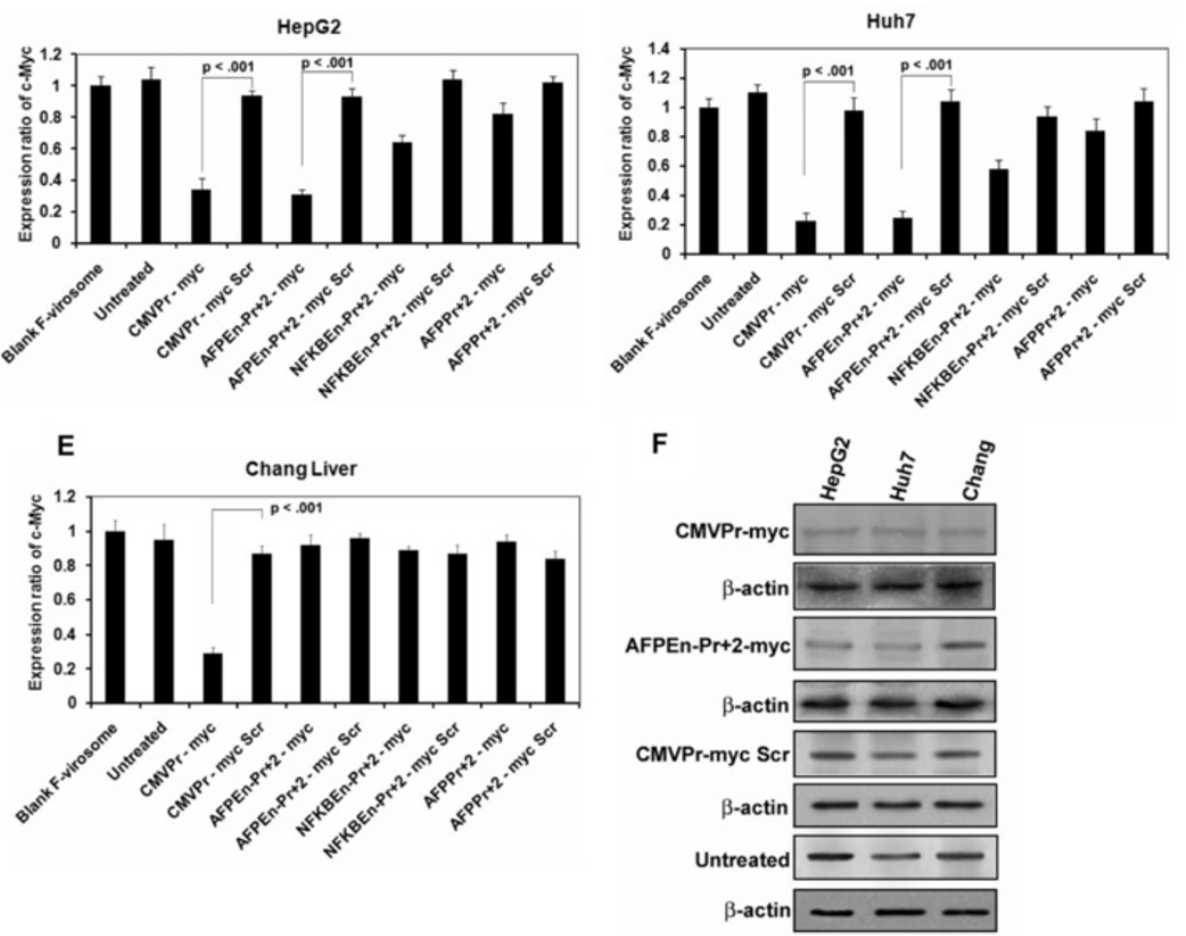

Figure 6 AFP promoter/enhancer +2 c-Myc shRNA delivered by F-virosomes down-regulated c-Myc. (A) Hemi fusion study in various hepatoma, untransformed and non-liver cells was done by fluorescence dequenching assay. Fusion of R18 labeled Sendai F-virosomes was determined by spectro-fluorimetry and was almost similar in the case of HepG2 and Huh7, whereas it was slightly lesser with Chang Liver cells. CHO cells, being a non-liver cell line, lack ASGPR and served as a negative control. F-virosomes with inactivated F-protein (HC: Heat Control) displayed poor fusion with the HepG2 cells. (B) Time dependant fall in the expression of c-Myc by AFPEn-Pr $+2-$ myc after virosomal delivery to HepG2 cells was significantly comparable with that of Lipofectamine ${ }^{\mathrm{TM}} 2000$ (C) In HepG2 cells, AFPEn-Pr +2 - myc construct decreases c-Myc level significantly which was comparable to that of the positive control CMVPr - myc. (D) Similar pattern was observed in the case of Huh7. (E) Down-regulation of c-Myc in untransformed Chang Liver cell line was observed only by CMVPr - myc and not by AFP promoter/enhancer driven shRNA. (F) Western Blot Analysis of c-Myc in HepG2, Huh7 and Chang Liver was in concordance with real-time PCR analysis and followed the same trend.

Figure S13). On day 6, c-Myc mRNA was continued to be suppressed (Figure 2C and 6B) and all the molecular markers of TGS were present (Figure 8). On day 7, almost all the cells detached from the culture plate due to extensive cell death, making it impossible to do any mRNA/ shRNA quantitation. This supports the possibility that TGS continues even after the reduction of shRNA, even though because of cell death, we were unable to reach zero expression.

\section{Discussion}

Specificity is the cornerstone of cancer therapy and a considerable part of the current research on cancer therapeutics tries to address this issue in the context of efficacy. 
In this study, we have tried to combine modalities for achieving specificity at two levels - that of the delivery system as well as the transcription of its cargo. This approach has been utilized for the expression of shRNA for inducing the suppression of $c-M y c$ by TGS. Although majority of the $c-M y c$ transcripts are $\mathrm{P} 2$ promoter driven [26], targeting approaches are hindered by the lack of specificity. Since $c-M y c$ is required for normal growth and proliferation, its non specific suppression might lead to hazarduous effects [54].

Sendai virosomes are naturally hepatotropic in nature because of their internalization through the ASGPRs of hepatocytes [14]. One of us has earlier described their properties both in vitro and in vivo and has used this system for gene delivery to hepatocytes in the Gunn rat model with good efficacy [15]. Sendai virosomes were shown to have high degree of direct cytoplasmic delivery with low immunogenicity [15-17].

At the second level of specificity we have tried to use liver tumour specific AFP promoter based fusion constructs. The AFP promoter has been used earlier to drive specific genes, mostly apoptotic or pro-drug metabolizing enzymes in hepatoma cells [55-59]. However, in our study, we have taken the minimal AFP promoter and added upstream enhancer regions from the AFP gene itself and, in another construct, the NFKB response element. This was done to increase the extent of promoter specific gene expression. Our studies showed that the AFP promoter fused with AFP enhancer (AFPEn-Pr + 25), had the strongest and specific expression in HCC cells.

As demonstrated by Dual Luciferase Assay, various AFP promoter based enhancer sytems specifically and optimally expressed luciferase in hepatoma models HepG2 and Huh7 but not in untransformed Chang Liver and non liver $\mathrm{CHO}$ cells (Figure 1B-E). Only the positive control construct (SV40 - luc) expressed luciferase in both Chang Liver and $\mathrm{CHO}$ cells because of its nonspecific nature (Figure 1D and E).

The specially designed AFP promoter/enhancer driven $c-M y c$ shRNA encompassing ME1a1 site upstream of $c$ $M y c$ P2 promoter resulted in reduced $c-M y c$ expression only in transformed hepatocarcinoma cells (Figure 2D and E). However, due to its universal nature, CMVPr myc decreased the level of $c-M y c$ even in Chang Liver and $\mathrm{CHO}$ cells (Figure $2 \mathrm{~F}$ and $\mathrm{G}$ ). The suppression of $c-M y c$ in transformed cells was in concordance with the strength of each construct (Figure 2D-G). The AFP Enhancer - AFP promoter construct was equivalent in strength to the known constitutive viral promoter CMV and stronger than SV40, while retaining specificity for HCC cells. However, Huh7 having lower basal level of $c-M y c$ compared to HepG2 was less responsive to $c-M y c$ suppression. Previous studies have shown that $c-M y c$ could abrogate the p53-induced cell-cycle arrest
[60], and it is possible that HepG2 cells, which contain wild-type p53 compared to mutant p53 in Huh7 [61], were more sensitive to $c-M y c$ suppression. Additionally, increased activity of $\mathrm{Wnt} / \beta$-catenin pathway in HepG2 than Huh7, which is a direct regulator of $c-M y c$ [62], also might add on to the greater $c-M y c$ level and its consequent implications in HepG2.

$c-M y c$ suppressed cells showed decreased cell survival and increased apoptosis, as evaluated by MTT Assay and Flow Cytometric analysis respectively (Figures 3 and 5). Moreover, cell survival estimated by trypan blue cell counting corroborated with the MTT data (Figure 4). This was concordant with the strength of promoter/ enhancer construct driving shRNA expression. The effect on HepG2 cells (Figures 3A, 4A and 5A) were more pronounced than that of Huh7 cells (Additional file 4: Figure S8, S9 and S10). However, no decrease in cell viability was observed in the case of Chang Liver cells as the AFP promoter based system was inactive in these cells (Figures 3B and 4B). Moreover, the specificity for transformed hepatocytes was clear as $c-M y c$ shRNA under the CMV promoter induced apoptosis even in Chang Liver cells (Figure 5B). Due to $c-M y c$ suppression, via TGS, majority of the transformed cells were found to be present within the subG1 phase followed by G0-G1 phase.

Since the use of antisense oligonucleotides or siRNA/ shRNA is potentially limited by ineffective delivery into cancer cells [63], to ensure specific and substantial level of therapeutic entry, shRNA constructs were packaged and delivered to various cell lines through Sendai F-virosomal system. Post virosomal delivery, the reduction in the level of $c-M y c$ was significantly comparable to that by conventional transfection reagent (Figures 2 and 6).

$c-M y c$ shRNA did not induce IFN response since there was no significant increase in the level of IFN marker OAS1 in HepG2, Huh7 and Chang Liver cells, post 5 days of virosomal delivery (Figure 7A) as well as at earlier time points (up to 4 days; Additional file 4: Figure S11 ). Some of the $c-M y c$ effector molecules are hTERT [64] and Cyclin D3 [65]. Although hTERT is not oncogenic per se, the activation of hTERT is essential for maintaining neoplastic transformation [66]. Following virosomal delivery of AFPEn-Pr + 2 - myc, significant decrease in hTERT and Cyclin D3 mRNA and protein was observed in HepG2 cells following $c-M y c$ suppression (Figure $7 \mathrm{~B}$ and $\mathrm{C}$ ). Furthermore, the more pronounced increase in caspase $3 / 7$ activity in HepG2 and not in Chang Liver was in agreement with Flow cytometric studies (Figure 7D).

Earlier reports of TGS have shown that silencing occurs through histone modifications [67-69], CpG methylation $[70,71]$ or interference of RNA polymerase binding [52]. In our case, we could demonstrate the induction of TGS by both heterochromatization and DNA methylation. 


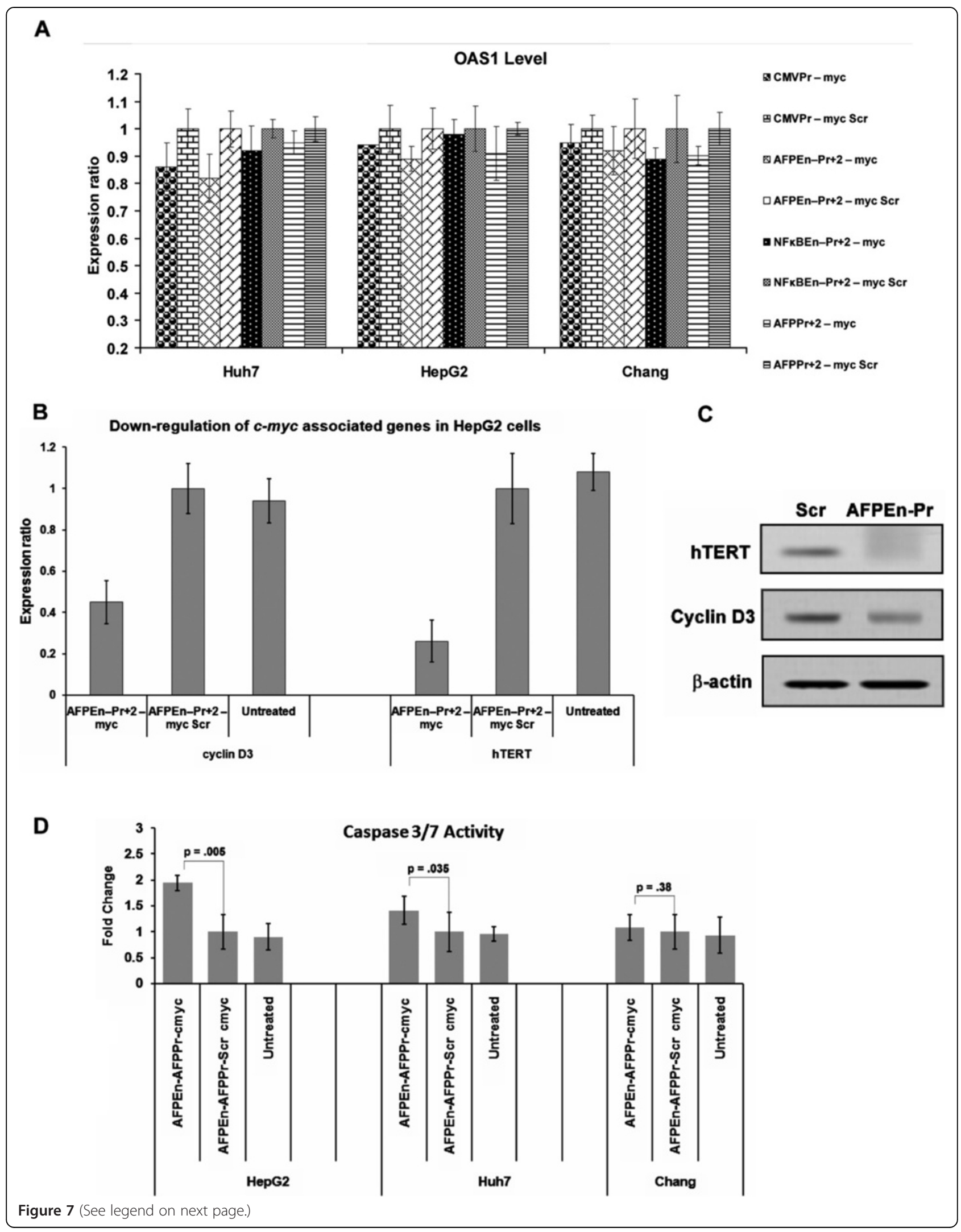




\section{(See figure on previous page.)}

Figure 7 Evaluation of interferon response, Cyclin D3, hTERT and caspase activity post TGS of c-Myc. (A) No Significant induction of OAS1 levels were seen in HepG2, Huh7 and Chang Liver cells, post 5 days of virosomal delivery, by chimeric AFP promoter driven shRNA constructs, confirming the absence of interferon response ( $p>0.05$ at all point). (B) Decrease in the RNA level of both Cyclin D3 and hTERT ( $p=0.0022$ and $p<0.001$ respectively) following c-myc suppression was seen in HepG2 cells through AFPEn-Pr $+2-$ myc when compared to its control AFPEn-Pr +2 - myc Scr. (C) Similar results were observed at the protein level. (D) c-Myc suppression by AFPEn-Pr $+2-$ myc, post 5 days after virosomal delivery, led to increase in caspase $3 / 7$ activity in HepG2 cells $(p=0.005)$ and Huh7 cells $(p=0.035)$. However, increase in caspase $3 / 7$ activity in Huh7 was to a lesser degree. No such increase was observed in the case of Chang Liver cell line $(p=0.38)$.
Previously, other groups have targeted different regions of $c-M y c$ promoter by siRNAs. siRNA against $c-M y c$ transcription start site has shown promising results in suppressing prostate cancer cells, for a longer duration, by interfering with the binding of RNA polymerase [52]. The same group has recently shown an effective strategy in suppressing prostate cancer stem cells, with good efficacy, both in culture and in mouse model through the promoter directed siRNAs [72]. Small molecule inhibitor of $c-M y c$ has proved useful in suppressing as well as chemo sensitizing HepG2 cells towards conventional drugs [73]. Additionally, several reports have demonstrated that suppression in $c$-Myc levels induces shrinkage in tumour volume [30-32].

In published literature, it is indicated that while PTGS would require sustained presence of the effector siRNA molecule, TGS would be long lasting, by virtue of its capability to induce heritable epigenetic changes [37,74]. Hence PTGS would also work in this cell specific promoter/delivery system albeit possibly for a shorter duration. However, we have not demonstrated the same experimentally. There is a report that after 7 days of continuous induction by siRNA against human ubiquitin c gene's (UbC) promoter, TGS persisted for over a month [39]. In a recent study from our lab, TGS of HIV clade C LTR was shown to be effective for at least 21 days after siRNA transfection [53].

In our study, we could follow the expression of $c-M y c$ mRNA and shRNA for only 6 days after transfection (Figures 2C and 6B and Additional file 5: Figure S13). Extensive cell death, of HepG2 cells, prevented us from quantifying mRNA and shRNA levels on day 7 and beyond. While on day 6 , shRNA levels were around $18 \%$ of the maximum (on day 2), the molecular markers of TGS were observed to be sustained (Figure 8). This indicates the possibility of a long term sustainability of TGS, even when shRNA levels have declined, although the persistence of TGS in the absolute absence of shRNA could not be determined because of the extensive cell death on day 7. In this study we observed that TGS could result in the reduction of $c-M y c$ for up to 6 days after single transfection.

By ChIP assay and bisulfite PCR/DNA sequencing, we demonstrated that the shRNA induces both histone and DNA methylation in HepG2 cells, which is accompanied by reduced $c-M y c$ promoter acetylation (Figure 8 ). This was also confirmed by RT-PCR, since the test shRNA failed to decrease $c-M y c$ transcript levels significantly in cells pretreated with both AZA and TSA (Additional file 5: Figure S12). In our earlier report, we were successfully able to induce TGS in glioma cell line U87 and this was shown to be by DNA methylation [34]. The current study is based on HCC cells and involves both heterochromatization and DNA methylation. It is possible that the variation in HDAC involvement is related to the cell type. As the primary message in the paper is related to the internalization of cargo via the ASGPRs, we have not explored the subtle differences in the mechanism of $c-M y c$ TGS in this study.

Here we have demonstrated two levels of specificity by combining a liver cell specific delivery system with a hepatocarcinoma specific promoter/enhancer system. The effector arm of the system is the shRNA inducing TGS of $c-M y c$. With this we have been able to demonstrate silencing of the $c-M y c$, specifically in transformed liver cells, leading to extensive cell death. It is expected that combined cell delivery/transformation specific gene expression system, would be a prototype for therapeutic gene delivery in transformed cells. The shRNA inducing TGS of $c-M y c$, would also serve as an effective mechanism for inducing cell death in the targeted cells.

\section{Conclusions}

The dual specificity resulting from Sendai F-virosomal delivery and tumour specific activation offers a novel mode of targeting $\mathrm{HCC}$ at two levels, first by targeted liver cell specific delivery and secondly by promoter/enhancer driven expression only in transformed hepatocarcinoma cells. Such approaches might also be utilized for other therapeutic modalities that are based on specific gene transcription e.g. Gene dependent enzyme prodrug therapy (GDEPT). shRNA induced suppression of $c-M y c$ expression by TGS is a possible gene therapy modality that could be utilized in such a delivery system. In the long run, such a targeting system may also be considered for introducing specific genes for expression in the embryonic liver or putting a check on recalcitrant cancer cells with deregulated $c-M y c$. 
A

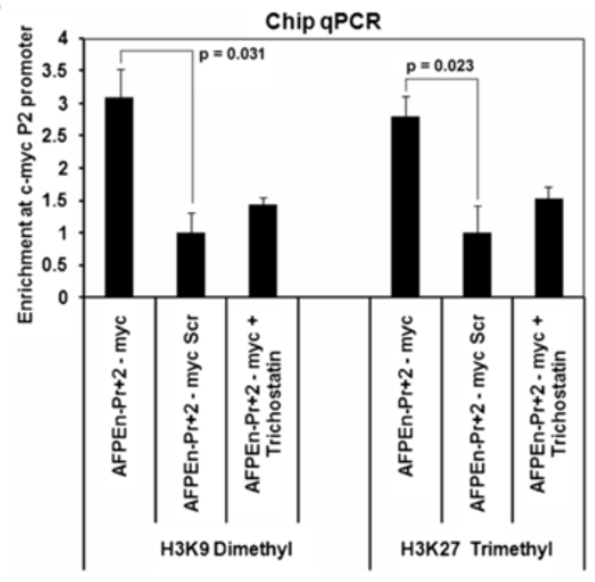

B

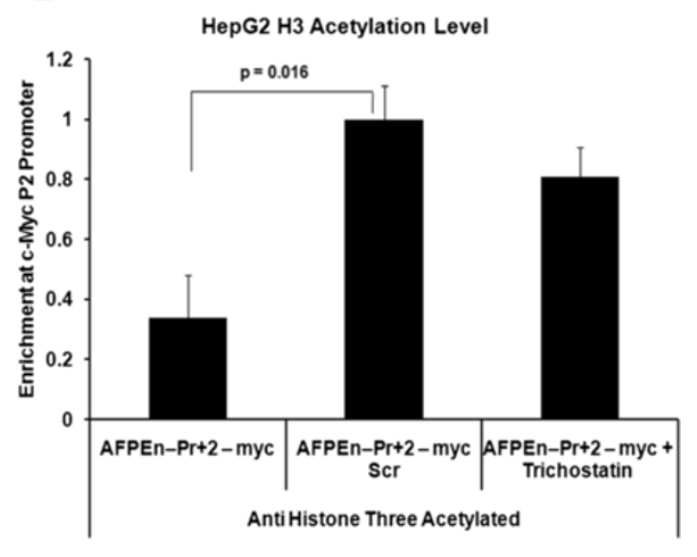

C

AFPEn-Pr+2 - myc Scr (Control shRNA)

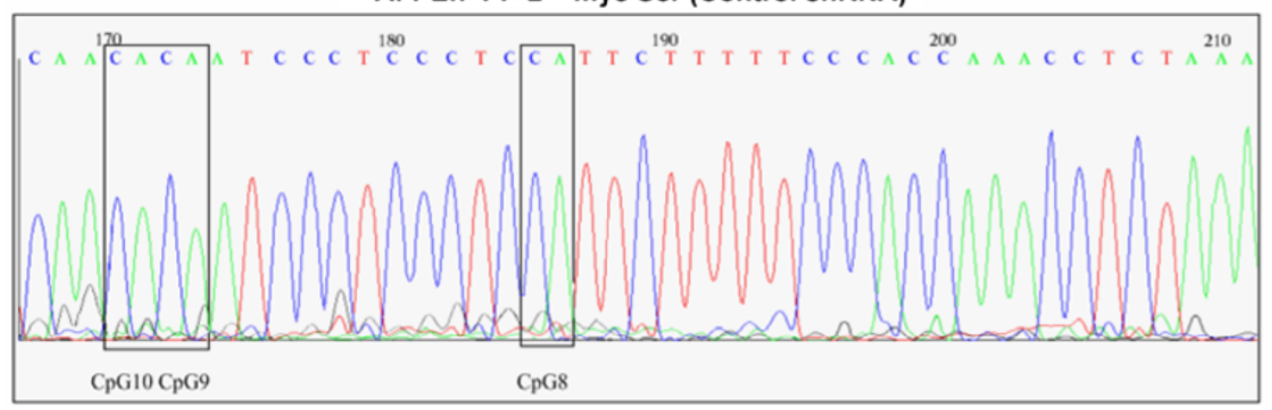

D

AFPEn-Pr+2 - myc (Test shRNA)

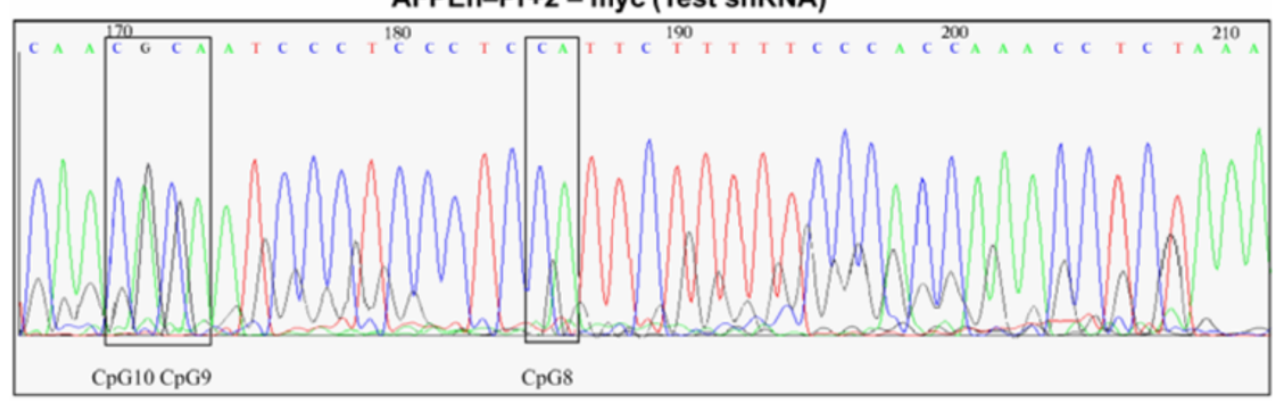

E

AFPEn-Pr+2 - myc(Test shRNA+AZA)

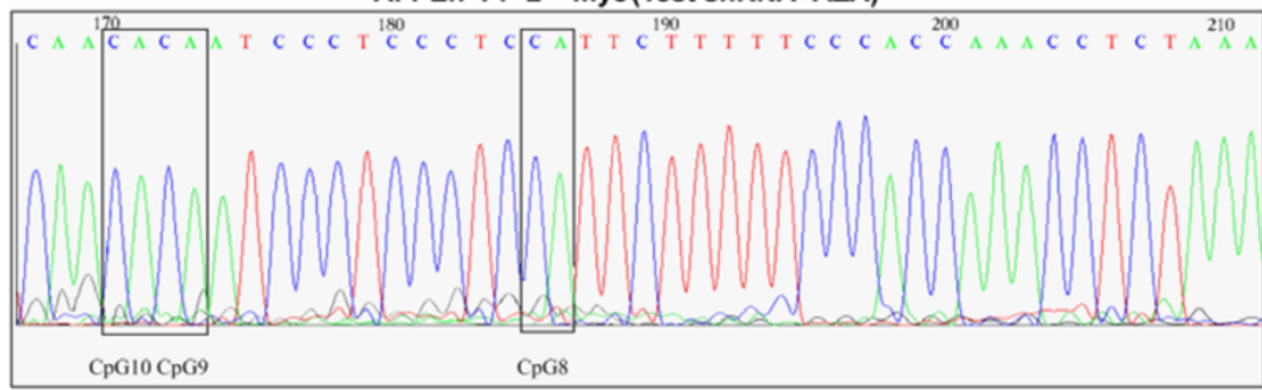

Figure 8 (See legend on next page.) 


\section{(See figure on previous page.)}

Figure 8 c-Myc shRNA induced epigenetic modifications around the target loci. (A) As evaluated by Chip Assay followed by qPCR, significant enrichment of both H3K9Me2 ( $p=0.031)$ and H3K27Me3 $(p=0.023)$ was found at $c-$ Myc P2 promoter on the $6^{\text {th }}$ day after virosomal delivery of AFPEn-Pr $+2-$ myc, whereas its scrambled control did not elicit the same level of enrichment. However, HepG2 cells pre-treated with TSA, did not show significant enrichment of both H3K9Me2 ( $p=0.55)$ and H3K27Me3 ( $p=0.37)$ by AFPEn-Pr $+2-$ myc shRNA construct. This indicates that in the presence of TSA, shRNA failed to induce significant heterochromatization around the target site. (B) 6 days post transfection of AFPEn-Pr +2 - myc in HepG2 cells, acetylation status of the c-Myc P2 promoter was evaluated by utilizing anti-histone 3 acetylated antibodies for ChIP assay followed by quantitative RT-PCR. The acetylation level significantly reduced post shRNA treatment $(p=0.016)$. However, no decrease in the acetylation level, by shRNA, was observed in the TSA treated HepG2 cells when compared to the scrambled control ( $p>0.05)$. This indicates shRNA mediated possible recruitment of HDACs at the target site causing de-acetylation, which was reversed upon treatment with TSA. (C, D and E) On the $6^{\text {th }}$ day following F-virosomal delivery of AFPEn-Pr +2 - myc in HepG2 cells, bisulfite PCR products were analyzed for methylation by DNA sequencing. (C) Sequence chromatogram result shows that methylation was induced by test c-Myc shRNA on CpG 8, 9 and 10 of c-Myc P2 promoter. (D) No methylation was induced by control shRNA. (E) Cells pretreated with AZA shows no methylation even by the test shRNA, indicating failure in the recruitment of DNMTs by the shRNA at the target site.

\section{Additional files}

Additional file 1: Figure S1. Molecular characterization of Chang Liver cell line.

Additional file 2: Figure S2. Clones of various AFP promoter/enhancer driven luciferase constructs. (A) AFPPr +25 - luc clone was confirmed by restriction digestion with Mlul and Nhel restriction enzymes. (B) AFPEn-Pr + 25 - luc was digested with Kpnl and Mlul restriction endonulceases and (C) NFkBEn-Pr + 25 - luc with Kpnl and Nhel.

Figure S3. Sequence of $c-M y c$ P2 promoter with siRNA target site and CpG islands. GAACGGAGGGAGGGATCGCGCT is the siRNA target site for P2 promoter of c-myc and contain CpG sites 8, 9 and 10. CpG sites are highlighted in red. TATAAAAG represents the TATA box. Figure S4. AFP promoter - c-myc shRNA (AFPPr $+2-$ myc) clone. (A) Schematic representation for cloning of AFPPr $+2-$ myc construct. (B) Annealed c-myc sense and antisense oligos. (C) AFPPr $+2-$ myc clone confirmation by digestion with EcoRl and Hindlll restriction enzymes. Figure S5. NFKB - c-myc shRNA (NFKBEn-Pr +2 - myc) clone. (A) Cloning strategy followed for the generation of this construct. (B) NFKB conjugated c-myc shRNA was confirmed by EcoRI and Hindlll digestion. Figure S6. AFP enhancer - AFP promoter - c-myc shRNA (AFPEn-Pr +2 - myc) clone. (A) Cloning strategy followed for the generation of this construct. (B) AFP enhancer and promoter conjugated c-myc shRNA was confirmed by EcoRI and Hindlll digestion.

Additional file 3: Table S1. Sequence of the primers used in the study. Additional file 4: Figure S7. Sequences of AFP promoter, enhancer and NFKB response element used in the study. (A) AFP Promoter sequence from - 230 to +25 bp. (B) AFP Enhancer. (C) Sequence of NFkB responsive element ( $4 \times 10$ copies). Figure S8. Cell survival of Huh7 cells, by MTT assay, following TGS of c-Myc. Following c-Myc suppression, Huh7 cells showed decreased cell survival but to a lesser degree when compared to that of HepG2. Figure S9. Cell survival of Huh7 cells, by Trypan Blue based cell counting, post c-Myc shRNA treatment. On the 6th day post transfection of all AFP promoter/enhancer driven c-Myc shRNA constructs, the decrease in cell survival of Huh7 corroborated with the MTT assay $(p<0.05)$. Figure S10. Evaluation of apoptosis in Huh7 cells by flow cytometry. Percentage of apoptotic cells, after c-Myc suppression via TGS, was dependent upon the strength of each construct driving ShRNA expression. Figure S11. Evaluation of Interferon response, in HepG2 cells, at various time point post F-virosomal delivery of c-Myc shRNA constructs. No significant increase in the levels of OAS1 was observed in $24,48,72$ and 96 hours post virosomal delivery of the entrapped shRNA plasmids ( $p>0.05$ at all points).

Additional file 5: Figure S12. Evaluation of c-Myc levels in HepG2 cells, pretreated with AZA/TSA or both in combination, followed by c-Myc shRNA transfection. HepG2 cells pretreated with TSA/AZA or both simultaneously were transfected with AFPEn - Pr $+2-$ myc and AFPEn-Pr $+2-$ myc Scr. On the $6^{\text {th }}$ day, real time PCR was done to evaluate the $c-M y c$ transcript levels. Significant decrease in the $c-M y c$ levels were observed in both AZA + AFPEn - Pr + 2- myc and TSA +
AFPEn - Pr $+2-$ myc treated HepG2 cells ( $p<0.05$ for both). Combined treatment of both AZA + TSA along with AFPEn - Pr + $2-$ myc showed no decrease in $c-M y c$ levels $(p>0.05)$. This confirmed that shRNA induces recruitment of both HDACs and DNMTs which play their part in $c-M y c$ down-regulation. Figure S13. Determination of shRNA expression in HepG2 cells at various time intervals by RT-PCR. c-Myc shRNA expression level was determined at various time points post transfection of c-Myc shRNA constructs. The expression of shRNA, by AFPEn $-\mathrm{Pr}+2-$ myc, was found to be maximum in 48 hours. The expression decreased significantly with time and was the lowest on day 6 (18\% of the maximum on day $2 ; p<0.05)$. shRNA, against luciferase mRNA, driven by CMV promoter (CMVPr - luc shRNA) was utilized as a control on day 1.

\section{Abbreviations}

HCC: Hepatocellular carcinoma; AFP: Alpha-fetoprotein; F-protein: Fusion protein; ASGPRs: Asialoglycoprotein receptors; HN: Hemagglutinin neuraminidase; hUGT1A1: Human uridinediphosphoglucuronate glucuronosyltransferase-1A1; CEA: Carcinogenic embryonic antigen; PSA: Prostate specific antigen; siRNA: Small interfering RNA; PTGS: Posttranscriptional gene silencing; dsRNA: Double stranded RNA; TGS: Transcriptional gene silencing; H3K9Me2: Histone three lysine nine dimethylated; H3K27Me3: Histone three lysine twenty seven trimethylated; shRNA: Short hairpin RNA; NFkB: Nuclear factor kappa beta; Pol III: Polymerase III; Pol II: Polymerase II; ATCC: American type cell culture; NCCS: National center for cell science; DMEM: Dulbecco's modified eagle's medium; bp: Base pairs; SV40: Simian virus 40; mM: Millimolar; EDTA: Ethylenediaminetetraacetic acid; TSS: Transcription start site; RNAi: RNA interference; Scr: Scrambled; CMV: Cytomegalovirus; RT-PCR: Real-time PCR; GAPDH: Glyceraldehyde 3-phosphate dehydrogenase; REST: Relative expression software tool; MTT: 3-(4,5-dimethylthiazol-2-yl)-2,5diphenyltetrazolium bromide; PI: Propidium lodide; SDS: Sodium dodecyl sulphate; R18: Rhodamine beta chloride; PBS: Phosphate buffered saline; rpm: Revolutions per minute; DTT: dithiothreitol; ChIP: Chromatin immunoprecipitation assay; HDAC: Histone deacetylase; DNMT: DNA methyl transferase; TSA: Trichostatin A; AZA: 5-aza-2deoxycytidine; HC: Heat control; IFN: Interferon; OAS1: Oligo adenylate synthetase 1; hTERT: Human telomerase reverse transcriptase; GDEPT: Gene dependent enzyme pro-drug therapy.

\section{Competing interests}

The authors declare that they have no competing interests.

\section{Authors' contributions}

MKZ and IK performed and designed majority of the experiments with the help of SS and PC. DPS supervised and PM assisted with the virosome related work. SS, DPS, PC, MKZ, IK, PM analyzed and interpreted the data. SS, MKZ, IK and PC prepared the manuscript. All authors approved the final manuscript.

\section{Acknowledgements}

This study was supported by Department of Biotechnology, Government of India (Grant No BT/PR13733/AGR/36/667/2010). J.C.Bose fellowship from the 
Department of Science and Technology and grant from Delhi University to Professor Debi P. Sarkar is highly acknowledged. Mohammad Khalid Zakaria and Imran Khan were supported by Indian Council of Medical Research (I.C. M.R) and University Grants Commission (U.G.C), Government of India respectively. We thank Mr. Pappu Prasad and Mr. Satish for their technical support.

\section{Author details}

${ }^{1}$ Department of Biochemistry, All India Institute of Medical Sciences, New Delhi 110029, India. ${ }^{2}$ Department of Biochemistry, University of Delhi, South Campus, Benito Juarez Road, New Delhi 110021, India. ${ }^{3}$ National Brain Research Centre, Manesar, Gurgaon, Haryana 122050, India.

Received: 4 April 2014 Accepted: 28 July 2014

Published: 10 August 2014

\section{References}

1. Forner A, Llovet JM, Bruix J: Hepatocellular carcinoma. Lancet 2012, 379:1245-1255.

2. Ali M, Sahib MK: Developmental changes in the expression of alphafetoprotein \& albumin genes in rat liver: correlation of rates of synthesis of the two proteins in the hepatocytes, their hepatic contents \& serum levels during development. Indian J Biochem Biophys 1983, 20:218-221.

3. Schiffelers RM, Ansari A, Xu J, Zhou Q, Tang Q, Storm G, Molema G, Lu PY, Scaria PV, Woodle MC: Cancer siRNA therapy by tumor selective delivery with ligand-targeted sterically stabilized nanoparticle. Nucleic Acids Res 2004, 32:e149.

4. Tang Q, Cao B, Wu H, Cheng G: Selective gene delivery to cancer cells using an integrated cationic amphiphilic peptide. Langmuir ACS J Surf Colloids 2012, 28:16126-16132.

5. Lee J, Yun K-S, Choi CS, Shin S-H, Ban H-S, Rhim T, Lee SK, Lee KY: $T$ cell-specific siRNA delivery using antibody-conjugated chitosan nanoparticles. Bioconjug Chem 2012, 23:1174-1180.

6. Kim S-H, Yang I-Y, Jang S-H, Kim J, Truong TT, Van Pham T, Truong NU, Lee $\mathrm{K}-\mathrm{Y}$, Jang $\mathrm{Y}$-S: C5a receptor-targeting ligand-mediated delivery of dengue virus antigen to $M$ cells evokes antigen-specific systemic and mucosal immune responses in oral immunization. Microbes Infect Inst Pasteur 2013, 15:895-902.

7. Han L, Guo Y, Ma H, He X, Kuang Y, Zhang N, Lim E, Zhou W, Jiang C: Acid active receptor-specific Peptide ligand for in vivo tumor-targeted delivery. Small Weinh Bergstr Ger 2013, 9:3647-3658.

8. Du W, Fan Y, Zheng N, He B, Yuan L, Zhang H, Wang X, Wang J, Zhang X, Zhang Q: Transferrin receptor specific nanocarriers conjugated with functional 7peptide for oral drug delivery. Biomaterials 2013, 34:794-806.

9. Li H, Qian ZM: Transferrin/transferrin receptor-mediated drug delivery. Med Res Rev 2002, 22:225-250.

10. Qian ZM, Li H, Sun H, Ho K: Targeted drug delivery via the transferrin receptor-mediated endocytosis pathway. Pharmacol Rev 2002, 54:561-587.

11. Zhao X, Li H, Lee RJ: Targeted drug delivery via folate receptors. Expert Opin Drug Deliv 2008, 5:309-319.

12. Jin L, Lee EM, Ramshaw HS, Busfield SJ, Peoppl AG, Wilkinson L, Guthridge MA, Thomas D, Barry EF, Boyd A, Gearing DP, Vairo G, Lopez AF, Dick JE, Lock RB: Monoclonal antibody-mediated targeting of CD123, IL-3 receptor alpha chain, eliminates human acute myeloid leukemic stem cells. Cell Stem Cell 2009, 5:31-42.

13. Yao Y, Sun T, Huang S, Dou S, Lin L, Chen J, Ruan J, Mao C, Yu F, Zeng M, Zang J, Liu Q, Su F, Zhang P, Lieberman J, Wang J, Song E: Targeted delivery of PLK1-siRNA by ScFv suppresses Her2+ breast cancer growth and metastasis. Sci Transl Med 2012, 4:130ra48.

14. Bagai S, Puri A, Blumenthal R, Sarkar DP: Hemagglutinin-neuraminidase enhances $F$ protein-mediated membrane fusion of reconstituted Sendai virus envelopes with cells. J Virol 1993, 67:3312-3318.

15. Wang X, Sarkar DP, Mani P, Steer CJ, Chen Y, Guha C, Chandrasekhar V, Chaudhuri A, Roy-Chowdhury N, Kren BT, Roy-Chowdhury J: Long-term reduction of jaundice in gunn rats by nonviral liver-targeted delivery of sleeping beauty transposon. Hepatol Baltim Md 2009, 50:815-824.

16. Verma SK, Mani P, Sharma NR, Krishnan A, Kumar W, Reddy BS, Chaudhuri A, Roy RP, Sarkar DP: Histidylated lipid-modified Sendai viral envelopes mediate enhanced membrane fusion and potentiate targeted gene delivery. J Biol Chem 2005, 280:35399-35409.
17. Sharma NR, Mani P, Nandwani N, Mishra R, Rana A, Sarkar DP: Reciprocal regulation of AKT and MAP kinase dictates virus-host cell fusion. J Virol 2010, 84:4366-4382.

18. Guo ZS, Li Q, Bartlett DL, Yang JY, Fang B: Gene transfer: the challenge of regulated gene expression. Trends Mol Med 2008, 14:410-418.

19. Robson T, Hirst DG: Transcriptional targeting in cancer gene therapy. J Biomed Biotechnol 2003, 2003:110-137.

20. Grünwald GK, Klutz K, Willhauck MJ, Schwenk N, Senekowitsch-Schmidtke R, Schwaiger M, Zach C, Göke B, Holm PS, Spitzweg C: Sodium iodide symporter (NIS)-mediated radiovirotherapy of hepatocellular cancer using a conditionally replicating adenovirus. Gene Ther 2013, 20:625-633.

21. Zhang K-J, Zhang J, Wu Y-M, Qian J, Liu X-J, Yan L-C, Zhou X-M, Xiao R-J, Wang Y-G, Cao X, Wei N, Liu X-R, Tang B, Jiao X-Y, Chen K, Liu X-Y: Complete eradication of hepatomas using an oncolytic adenovirus containing AFP promoter controlling E1A and an E1B deletion to drive IL-24 expression. Cancer Gene Ther 2012, 19:619-629.

22. Peng Y-F, Shi Y-H, Ding Z-B, Zhou J, Qiu S-J, Hui B, Gu C-Y, Yang H, Liu W-R, Fan J: Alpha-fetoprotein promoter-driven Cre/LoxP-switched RNA interference for hepatocellular carcinoma tissue-specific target therapy. PLoS One 2013, 8:e53072.

23. Qiao J, Doubrovin M, Sauter BV, Huang Y, Guo ZS, Balatoni J, Akhurst T, Blasberg RG, Tjuvajev JG, Chen S-H, Woo SLC: Tumor-specific transcriptional targeting of suicide gene therapy. Gene Ther 2002, 9:168-175.

24. Groupp ER, Crawford N, Locker J: Characterization of the distal alphafetoprotein enhancer, a strong, long distance, liver-specific activator. J Biol Chem 1994, 269:22178-22187.

25. Watanabe K, Saito A, Tamaoki T: Cell-specific enhancer activity in a far upstream region of the human alpha-fetoprotein gene. J Biol Chem 1987, 262:4812-4818.

26. Wierstra I, Alves J: The c-myc promoter: still MysterY and challenge. Adv Cancer Res 2008, 99:113-333.

27. Wilson A, Murphy MJ, Oskarsson T, Kaloulis K, Bettess MD, Oser GM, Pasche A-C, Knabenhans C, MacDonald HR, Trumpp A: c-Myc controls the balance between hematopoietic stem cell self-renewal and differentiation. Genes Dev 2004, 18:2747-2763.

28. Davis AC, Wims M, Spotts GD, Hann SR, Bradley A: A null c-myc mutation causes lethality before 10.5 days of gestation in homozygotes and reduced fertility in heterozygous female mice. Genes Dev 1993, 7:671-682.

29. Mateyak MK, Obaya AJ, Adachi S, Sedivy JM: Phenotypes of c-Mycdeficient rat fibroblasts isolated by targeted homologous recombination. Cell Growth Differ Mol Biol J Am Assoc Cancer Res 1997, 8:1039-1048.

30. Ebinuma H, Saito H, Saito Y, Wakabayashi K, Nakamura M, Kurose I, Ishii H: Antisense oligodeoxynucleotide against c-myc mRNA induces differentiation of human hepatocellular carcinoma cells. Int J Oncol 1999, 15:991-999.

31. Shachaf CM, Kopelman AM, Arvanitis C, Karlsson A, Beer S, Mandl S, Bachmann MH, Borowsky AD, Ruebner B, Cardiff RD, Yang Q, Bishop JM, Contag $\mathrm{CH}$, Felsher DW: MYC inactivation uncovers pluripotent differentiation and tumour dormancy in hepatocellular cancer. Nature 2004, 431:1112-1117.

32. Xu Y, Wang Y-H, Gao J-D, Ye J, Zhu H-X, Xu N-Z, Wang X-Y, Sun Z-T: Suppression of c-myc expression by interference RNA in HepG2 hepatocellular carcinoma cells. Zhonghua Zhong Liu Za Zhi 2004, 26:458-460.

33. Albert T, Wells J, Funk JO, Pullner A, Raschke EE, Stelzer G, Meisterernst M, Farnham PJ, Eick D: The chromatin structure of the dual c-myc promoter P1/P2 is regulated by separate elements. J Biol Chem 2001, 276:20482-20490.

34. Mehndiratta M, Palanichamy JK, Pal A, Bhagat M, Singh A, Sinha S, Chattopadhyay P: CpG hypermethylation of the C-myc promoter by dsRNA results in growth suppression. Mol Pharm 2011, 8:2302-2309.

35. Fire A, Xu S, Montgomery MK, Kostas SA, Driver SE, Mello CC: Potent and specific genetic interference by double-stranded RNA in Caenorhabditis elegans. Nature 1998, 391:806-811.

36. Hammond SM, Bernstein E, Beach D, Hannon GJ: An RNA-directed nuclease mediates post-transcriptional gene silencing in Drosophila cells. Nature 2000, 404:293-296.

37. Morris KV, Chan SW-L, Jacobsen SE, Looney DJ: Small interfering RNA-induced transcriptional gene silencing in human cells. Science 2004 305:1289-1292.

38. Suzuki K, Juelich T, Lim H, Ishida T, Watanebe T, Cooper DA, Rao S, Kelleher AD: Closed chromatin architecture is induced by an RNA duplex targeting the HIV-1 promoter region. J Biol Chem 2008, 283:23353-23363. 
39. Hawkins PG, Santoso S, Adams C, Anest V, Morris KV: Promoter targeted small RNAs induce long-term transcriptional gene silencing in human cells. Nucleic Acids Res 2009, 37:2984-2995.

40. Kim DH, Villeneuve LM, Morris KV, Rossi JJ: Argonaute-1 directs siRNA-mediated transcriptional gene silencing in human cells. Nat Struct Mol Biol 2006, 13:793-797.

41. Morris KV: Non-coding RNAs, epigenetic memory and the passage of information to progeny. RNA Biol 2009, 6:242-247.

42. Giering JC, Grimm D, Storm TA, Kay MA: Expression of shRNA from a tissue-specific pol II promoter is an effective and safe RNAi therapeutic. Mol Ther J Am Soc Gene Ther 2008, 16:1630-1636.

43. Arsura M, Cavin LG: Nuclear factor-kappaB and liver carcinogenesis. Cancer Lett 2005, 229:157-169.

44. Kanai F: Transcriptional targeted gene therapy for hepatocellular carcinoma by adenovirus vector. Mol Biotechnol 2001, 18:243-250.

45. Pranski EL, Dalal NV, Herskowitz JH, Orr AL, Roesch LA, Fritz JJ, Heilman C, Lah JJ, Levey Al, Betarbet RS: Neuronal RING finger protein 11 (RNF11) regulates canonical NF-KB signaling. J Neuroinflammation 2012, 9:67.

46. Xia H, Mao Q, Paulson HL, Davidson BL: siRNA-mediated gene silencing in vitro and in vivo. Nat Biotechnol 2002, 20:1006-1010.

47. Vandesompele J, De Preter K, Pattyn F, Poppe B, Van Roy N, De Paepe A, Speleman F: Accurate normalization of real-time quantitative RT-PCR data by geometric averaging of multiple internal control genes. Genome Biol 2002, 3:RESEARCH0034

48. Pfaffl MW, Horgan GW, Dempfle L: Relative expression software tool (RESTC) for group-wise comparison and statistical analysis of relative expression results in real-time PCR. Nucleic Acids Res 2002, 30:e36.

49. Haring M, Offermann S, Danker T, Horst I, Peterhansel C, Stam M: Chromatin immunoprecipitation: optimization, quantitative analysis and data normalization. Plant Methods 2007, 3:11

50. Sledz CA, Holko M, de Veer MJ, Silverman RH, Williams BRG: Activation of the interferon system by short-interfering RNAs. Nat Cell Biol 2003, 5:834-839.

51. Scacheri PC, Rozenblatt-Rosen O, Caplen NJ, Wolfsberg TG, Umayam L, Lee JC, Hughes CM, Shanmugam KS, Bhattacharjee A, Meyerson M, Collins FS: Short interfering RNAs can induce unexpected and divergent changes in the levels of untargeted proteins in mammalian cells. Proc Natl Acad Sci US A 2004, 101:1892-1897.

52. Napoli S, Pastori C, Magistri M, Carbone GM, Catapano CV: Promoterspecific transcriptional interference and c-myc gene silencing by siRNAs in human cells. EMBO J 2009, 28:1708-1719.

53. Singh A, Palanichamy JK, Ramalingam P, Kassab MA, Bhagat M, Andrabi R, Luthra K, Sinha S, Chattopadhyay P: Long-term suppression of HIV-1C virus production in human peripheral blood mononuclear cells by LTR heterochromatization with a short double-stranded RNA. J Antimicrob Chemother 2014, 69:404-415.

54. Lin C-P, Liu C-R, Lee C-N, Chan T-S, Liu HE: Targeting c-Myc as a novel approach for hepatocellular carcinoma. World J Hepatol 2010, 2:16-20.

55. Cai X, Zhou J, Chang Y, Sun X, Li P, Lin J: Targeting gene therapy for hepatocarcinoma cells with the E. coli purine nucleoside phosphorylase suicide gene system directed by a chimeric alpha-fetoprotein promoter. Cancer Lett 2008, 264:71-82.

56. Cao G, Kuriyama S, Tsujinoue H, Chen Q, Mitoro A, Qi Z: A novel approach for inducing enhanced and selective transgene expression in hepatocellular-carcinoma cells. Int J Cancer 2000, 87:247-252.

57. Cao G, Kuriyama S, Gao J, Nakatani T, Chen Q, Yoshiji H, Zhao L, Kojima H, Dong Y, Fukui H, Hou J: Gene therapy for hepatocellular carcinoma based on tumour-selective suicide gene expression using the alpha-fetoprotein (AFP) enhancer and a housekeeping gene promoter. Eur J Cancer Oxf Engl 1990 2001, 37:140-147.

58. Kanai F, Lan KH, Shiratori Y, Tanaka T, Ohashi M, Okudaira T, Yoshida Y, Wakimoto H, Hamada H, Nakabayashi H, Tamaoki T, Omata M: In vivo gene therapy for alpha-fetoprotein-producing hepatocellular carcinoma by adenovirus-mediated transfer of cytosine deaminase gene. Cancer Res 1997, 57:461-465

59. Willhauck MJ, Sharif Samani BR, Klutz K, Cengic N, Wolf I, Mohr L, Geissler M, Senekowitsch-Schmidtke R, Göke B, Morris JC, Spitzweg C: Alpha-fetoprotein promoter-targeted sodium iodide symporter gene therapy of hepatocellular carcinoma. Gene Ther 2008, 15:214-223.

60. Ho JSL, Ma W, Mao DYL, Benchimol S: p53-dependent transcriptional repression of c-myc is required for G1 cell cycle arrest. Mol Cell Biol 2005, 25:7423-7431.
61. Müller M, Strand S, Hug H, Heinemann EM, Walczak H, Hofmann WJ, Stremmel W, Krammer PH, Galle PR: Drug-induced apoptosis in hepatoma cells is mediated by the CD95 (APO-1/Fas) receptor/ligand system and involves activation of wild-type p53. J Clin Invest 1997, 99:403-413.

62. Wei W, Chua M-S, Grepper S, So SK: Soluble Frizzled-7 receptor inhibits Wnt signaling and sensitizes hepatocellular carcinoma cells towards doxorubicin. Mol Cancer 2011, 10:16.

63. Robinson R: RNAi therapeutics: how likely, how soon? PLoS Biol 2004, 2:e28.

64. Wu KJ, Grandori C, Amacker M, Simon-Vermot N, Polack A, Lingner J, Dalla-Favera R: Direct activation of TERT transcription by c-MYC. Nat Genet 1999, 21:220-224.

65. Jänicke RU, Lin XY, Lee FH, Porter AG: Cyclin D3 sensitizes tumor cells to tumor necrosis factor-induced, c-Myc-dependent apoptosis. Mol Cell Biol 1996, 16:5245-5253.

66. Jang KY, Noh SJ, Lehwald N, Tao G-Z, Bellovin DI, Park HS, Moon WS, Felshe DW, Sylvester KG: SIRT1 and c-Myc promote liver tumor cell survival and predict poor survival of human hepatocellular carcinomas. PLoS One 2012, 7:e45119.

67. Gonzalez S, Pisano DG, Serrano M: Mechanistic principles of chromatin remodeling guided by siRNAs and miRNAs. Cell Cycle Georget Tex 2008 7:2601-2608.

68. Palanichamy JK, Mehndiratta M, Bhagat M, Ramalingam P, Das B, Das $P$, Sinha S, Chattopadhyay P: Silencing of integrated human papillomavirus-16 oncogenes by small interfering RNA-mediated heterochromatization. Mol Cancer Ther 2010, 9:2114-2122.

69. Weinberg MS, Villeneuve LM, Ehsani A, Amarzguioui M, Aagaard L, Chen Z-X, Riggs AD, Rossi JJ, Morris KV: The antisense strand of small interfering RNAs directs histone methylation and transcriptional gene silencing in human cells. RNA N Y N 2006, 12:256-262.

70. Hoffman AR, Hu JF: Directing DNA methylation to inhibit gene expression. Cell Mol Neurobiol 2006, 26:425-438.

71. Tufarelli C, Stanley JAS, Garrick D, Sharpe JA, Ayyub H, Wood WG, Higgs DR: Transcription of antisense RNA leading to gene silencing and methylation as a novel cause of human genetic disease. Nat Genet 2003, 34:157-165.

72. Civenni G, Malek A, Albino D, Garcia-Escudero R, Napoli S, Di Marco S, Pinton S, Sarti M, Carbone GM, Catapano CV: RNAi-mediated silencing of Myc transcription inhibits stem-like cell maintenance and tumorigenicity in prostate cancer. Cancer Res 2013, 73:6816-6827.

73. Lin C-P, Liu J-D, Chow J-M, Liu C-R, Liu HE: Small-molecule c-Myc inhibitor, 10058-F4, inhibits proliferation, downregulates human telomerase reverse transcriptase and enhances chemosensitivity in human hepatocellular carcinoma cells. Anticancer Drugs 2007, 18:161-170.

74. Morris KV: Long antisense non-coding RNAs function to direct epigenetic complexes that regulate transcription in human cells. Epigenetics Off J DNA Methylation Soc 2009, 4:296-301.

doi:10.1186/1471-2407-14-582

Cite this article as: Zakaria et al:: Combination of hepatocyte specific delivery and transformation dependent expression of shRNA inducing transcriptional gene silencing of c-Myc promoter in hepatocellular carcinoma cells. BMC Cancer 2014 14:582.

\section{Submit your next manuscript to BioMed Central and take full advantage of:}

- Convenient online submission

- Thorough peer review

- No space constraints or color figure charges

- Immediate publication on acceptance

- Inclusion in PubMed, CAS, Scopus and Google Scholar

- Research which is freely available for redistribution 